\title{
ANÁLISE DO POTENCIAL GENÉTICO DE CULTIVARES DE SOJA [Glycine max (L.) MERRILL] ATRAVÉS DE CRUZAMENTOS DIALÉLICOS
}

\section{ESTEFANO PALUDZYSZYN FILHO}

Oriontador: Prof. Dr. JOSÉ BRANCO DE MIRANDA FILHO

Dissertação apresentada à Escola Superior de Agricultura "Luiz de Queiroz", da Universidade de São Paulo, para obtenção do título de Mestre em Genética o Melhoramento de Plantas.

PIRACICABA

Estado de São Paulo - Brasil

Janeiro, 1982 
.ii.

A esposa Elizabeth, Aos filhos, pais e irmãos, DEDICO. 
Ao professor Dr. NATAL ANTÔNIO VELLO, orientą dor inicial, pela dedicação, amizade e ensinamentos.

Ao professor Dr. JOSE BRANCO DE MIRANDA FILHO, pelos ensinamentos, pela orientação e empenho na realizaçãodes ta.

Ao convênio de cooperação EMBRAPA - ESALQ pela oportunidade concedida para realização das observações experị mentais em Londrina - Paranä.

Aos professores Dr. ERNESTO PATERNIANI e Dr. JO SE JOAQUIM DE CAMARGO ENGLER pelo apoio ao plano de pesquisa apresentado, respectivamente ao Departamento de Genética e ao Convênio EMBRAPA - ESALQ.

A Empresa Brasileira de Pesquisa Agropecuāria EMBRAPA pela oportunidade e ao. Centro Nacional de Pesquisa de Soja - CNPSo pelas facilidades oferecidas para realização des ta.

Aos colegas Dr, ROMEU AFONSO DE SOUZA KIIHL e Dr. JOSE FRANCISCO FERRAZ DE TOLEDO pela amizade, estímulo e rientação na realização das observações experimentais.

Aos colegas de estudo pela amizade e incentivo.

Aos professores e funcionärios do Departamento e Instituto de Genētica pelas ensinamentos e atenções. 


\section{CURRICULUM VITAE}

ESTEFANO PALUDZYSZYN FILHO, filho de stefan Pa Zudzyszyn e Catarina Paludzyszyn, nasceu a 30 de setembro de 1950 em Curitiba, Estado do Paranā. Em dezembro de 1974, gra duou-se Engenheiro Agronômo pela Faculdade de Agronomia da Uni versidade Federal do Paraná. Em fevereiro de 1975 foi contra tado pela Organização das Cooperativas do Estado do Paraná OCEPAR como pesquisador na ärea de melhoramento em soja. Em 1976 foi contratado pelo Instituto Agronômico do Paraná - IAPAR e posto a disposigão do Centro Nacional de Pesquisa de Soja da Empresa Brasileira de Pesquisa Agropecuária aonde foi contrata do em 1978. Em 1980, ingressou no Curso de Genética e Melhor $\underline{a}$ mento de Plantas do Departamento de Genêtica da Escola. Supe rior de Agricultura - ESALQ da Universidade de São Paulo-USP. 


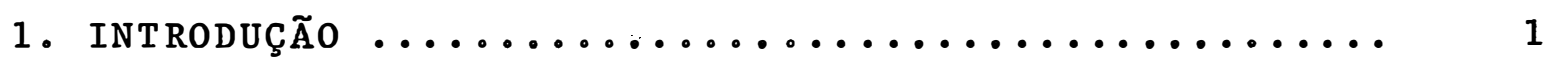

2. REvisão de literatura $\ldots \ldots \ldots \ldots \ldots \ldots \ldots \ldots \ldots \ldots$

2.1. O melhoramento e a genética quantitativa..... 4

2.2. Base genética e aproveitamento desta para pro dução de grãos.................... 7

2.3. Genética dos caracteres floração e maturação.. 13

2.4. Cruzamentos dialélicos.................. 14

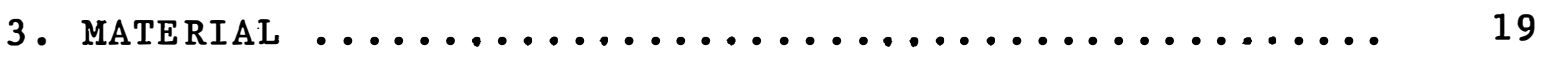

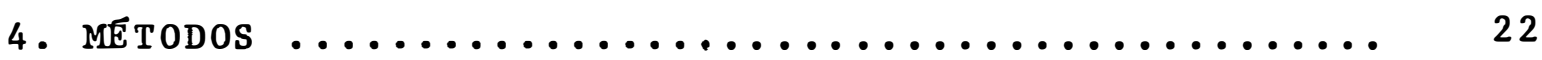

4.1. P1anejamento e execução experimenta1........ 22

4.2. Preparação das linhagens e cruzamentos....... 22

4.3. Caracteres observados................... 23

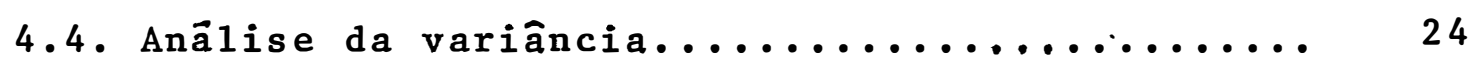

4.5. Anālise das tabelas dialêlicas e estimação de parâmetros genéticos de mêdias, dos efeitos de capacidade geral de combinação e das variân cias de c.g.c. e c.e.c. associadas as linhagens 24

4.6. Cálculo das heteroses mêdias das linhagens.... 32

4.7. Partição das estimativas dos efeitos de c.g.c. 33

4.8. Covariância entre estimativas dos efeitos de heterose de linhagens e efeitos de linhagens.. 33

4.9. Correlações entre as médias dos $F_{1}^{\prime}$ 's e as mé dias das respectivas 1 inhagens parentais..... 


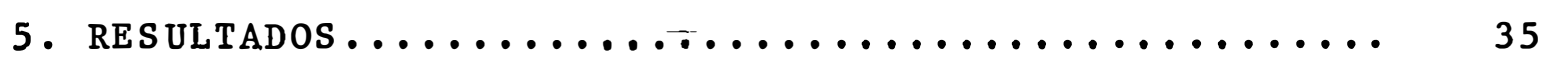

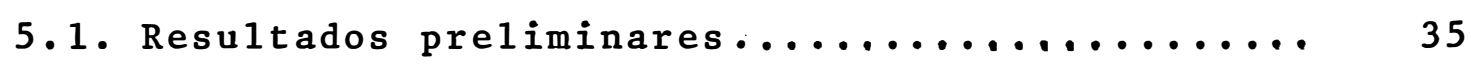

5.2. Resultados das anảlises das tabelas dialēlicas 37

5.3. Resultados das estimativas dos componentes de mëdias............................ 37

5.4. Resultados das heteroses mêdias das 1 inhagens...

5.5. Resultados das estimativas dos componentes de mẻdias, dos efeitos de c.g.c. e das variâncias associadas aos efeitos de c.g.c.e c.e.c. das

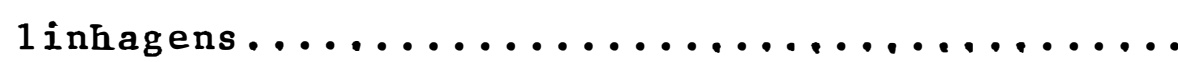

5.6. Resultados da partição das estimativas dos e feitos de c.g.c......................

5.7. Resultados da covariância entre estimativas dos efeitos de $\hat{l}_{i}$ e $\hat{h}_{i} \ldots \ldots \ldots \ldots \ldots \ldots \ldots \ldots \ldots \ldots \ldots \ldots \ldots \ldots \ldots \ldots \ldots$

5.8. Resultados das correlações entre as mẻdias dos $F_{1}$ 's e a média das respectivas linhagens paren

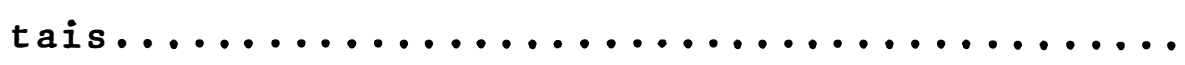

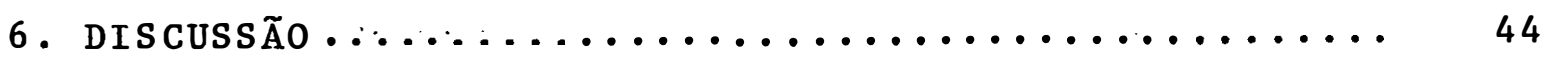

6.1. Avaliação das linhagens, heteroses e das cor

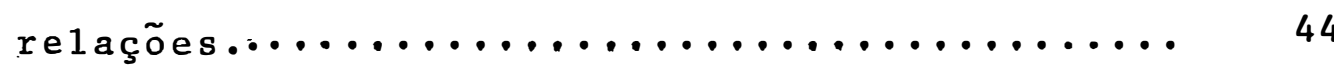

6.2. Anālise dos cruzamentos dialēlicos......... 49 6.2 .1 . Generalidades.................... 49

6.2.2. Estimativas dos efeitos de c.e.c. e.c.g.c. 54

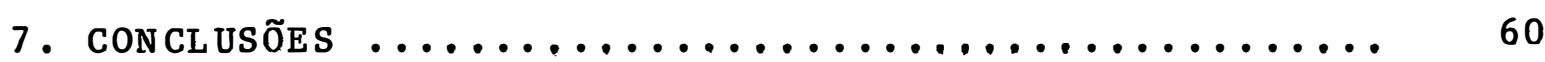


.vii.

pāgina

LITERATURA CITADA $\ldots \ldots \ldots \ldots \ldots \ldots \ldots \ldots \ldots \ldots \ldots \ldots \ldots \ldots \ldots$

TABELAS E FIGURAS $\ldots \ldots \ldots \ldots \ldots \ldots \ldots \ldots \ldots \ldots \ldots \ldots \ldots \ldots \ldots \ldots \ldots \ldots$

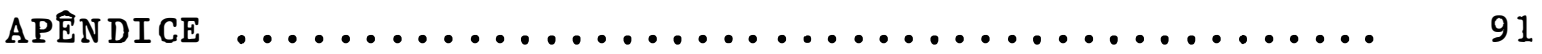


Tabe 1a

pâgina

1. Valores, significâncias dos quadrados mëdios e coefí cientes de variação obtidos nas anảlises da variân cia para os três caracteres em estudo: NDF: nủmero de dias para início da floração, NDM: númerode dias para maturação e PG: produção de grãos (g/planta). Blo cos casualizados com seis repetições. Londrina-PR,

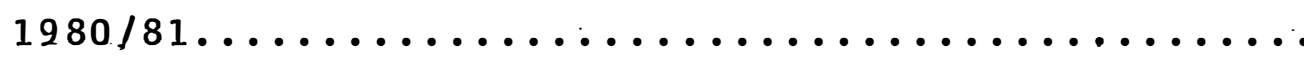

2. Mẻdias observadas do caräter nümero de dias para i nício da floração (NDF) de oito linhagens e respec tivos $F_{1}$ 's em cruzamentos dialëlicos. Mẻdias de duas plantas por vaso em seis repetições. $(1980 / 81) \ldots .$.

3. Mẻdias observadas do caräter nümero de dias para ma turação (NDM) de oito linhagens e respectivos $F_{1}$ 's em cruzamentos dialêlicos. Mẻdias obtidas de duas plantas por vaso em seis repetições. $(1980 / 81) \ldots .$.

4. Mẻdias observadas do carảter produção de grãos ( $P G$ em gramas por planta de oito linhagens e respectivos $F_{1}$ 's em cruzamentos dialēlicos. Mêdias de duas plan tas por vaso em seis repetições. $(1980 / 81) \ldots \ldots \ldots$... 
5. Valores e significâncias dos quadrados médios obti dos nas anālises da variância das tabelas dialêli cas segundo o modelo de GARDNER e EBERHART (1966) e da capacidade geral de combinação (c.g.c.) segun do o método 4, modelo I de GRIFFING (1956), para os três caracteres em estudo: NDF: nưmero de dias para início da floração, NDM: nümero de dias para maturação e PG: produção de grãos..............

6. Estimativas dos parâmetros: $\widehat{h}_{i j}$ - heterose do cruza mento ij (acima da diagonal), $\widehat{s}_{i j}$ - heterose espe cîfica ou capacidade especîfica de combinação (a baixo da diagona 1$)$, $\widehat{u}$ - mêdia das linhagens paren tais e $\widehat{\bar{h}}$ - heterose mêdia de todos os cruzamentos, para o carâter NDF: nümero de dias para início da floração.............................

7. Estimativas dos parâmetros: $\widehat{h}_{i j}$ - heterose do cruza mento ij (acima da diagona1), $\hat{s}_{i j}$ - heterose espe cîfica ou capacidade específica de combinação (a baixo da diagona12, $\widehat{u}$ - mẻdia das 1inhagens parentais e $\widehat{\bar{h}}$ - heterose mêdia de todos os cruzamentos, para o caráter NDM; nümero de dias para maturação. 
8. Estimativas dos parâmetros: $\hat{h}_{i j}$ - heterose do cruza mento ij (acima da diagonal), $\widehat{s}_{i j}$ - heterose espe cífica ou capacidade específica de combinação (abai xo da diagona1), $\widehat{u}$ - média das linhagens parentais e $\overline{\mathrm{h}}$ - heterose média de todos os cruzamentos, para - caráter PG: produção de grãos (g/planta).......

9. Estimativas das heteroses da produçãode grãos em por centagem da média dos parentais (acima da diago na1) e em porcentagem do parental superior (abaixo

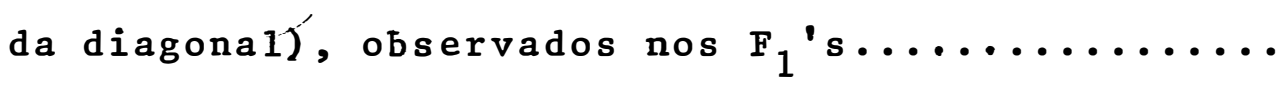

10. Heterose média das 1 inhagens parentais $\left(\bar{h}_{i}\right)$ resultantes dos cruzamentos em dialélico para os carac teres nümero de dias para início da floração (NDF), nümero de dias para maturação (NDM) e produção de grãos em gramas/planta e em porcentagem..........

11. Estimativas dos parâmetros: $\hat{l}_{i}$ - efeito de linhagens, $\hat{\mathrm{h}}_{i}$ - efeito de heterose das linhagens, $\hat{\mathrm{g}}_{i}$ - efeito de capacidade geral de combinação (c.g.c.) e as es timativas das variâncias das capacidades geral $\left(\hat{\sigma}^{2} \hat{g}_{i}\right)$ e específica $\left(\hat{\sigma}^{2} \hat{s}_{i}\right)$ de combinação das 1inha gens para o carāter NDF: número de dias para inî cio da floração......................... 
12. Estimativas dos parâmetros: $\hat{l}_{i}$ - efeito de linhagens, $\widehat{\mathrm{h}}_{\mathrm{i}}$ - efeito de heterose das linhagens, $\widehat{\mathrm{g}}_{\mathrm{i}}$ - efeito de capacidade geral de combinação (c.g.c.), e as es timativas das variâncias das capacidades geral $\left(\hat{\sigma}^{2} \widehat{\mathscr{E}}_{\mathbf{i}}\right)$ e específica $\left(\hat{\sigma}^{2} \hat{s}_{i}\right)$ de combinação das linhagens pa ra o carāter NDM: número de dias para maturação....

13. Estimativas dos parâmetros: $\hat{l}_{i}$ - efeito de linhagens, $\hat{\mathrm{h}}_{\mathrm{i}}$ - efeito de heterose das linhagens, $\hat{\mathrm{g}}_{\mathbf{i}}$ - efeito de capacidade geral de combinação (c.g.c.), e as estimativas das variâncias das capacidades geral $\left(\hat{\sigma}^{2} \hat{g}_{i}\right)$ e específica $\left(\hat{\sigma}^{2} \hat{s}_{i}\right)$ de combinação associada as 1 inhagens para o carāter PG: produção de grãos ( $g$ /

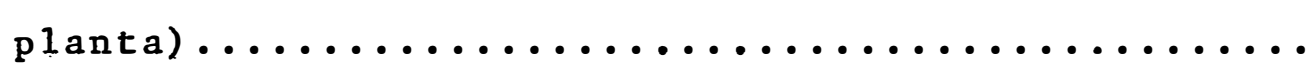

14. Decomposição dos componentes das estimativas dos feitos de capacidade geral de combinação $\left(\hat{g}_{i}\right)$ respec tivamente em efeitos de linhagens $\left(\hat{\ell}_{i}\right)$ e efeitos de heteroses das linhagens $\left(\hat{h}_{i}\right)$ em porcentagens para os três caracteres em estudo.................. 


\section{LISTA DE FIGURAS}

Figura

pāgina

1. Regressão linear entre as mëdias dos $F_{1}$ 's e respectivas linhagens parentais para o carāter nümero de

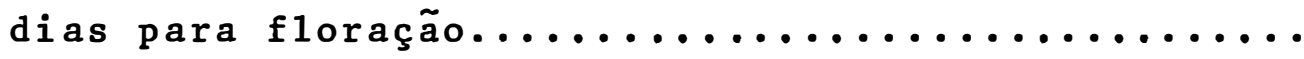

2. Regressão linear entre mêdias do nümero de dias pạ ra maturação dos $F_{1}$ 's e das respectivas linhagens parentais............................

3. Regressão linear entre médias da produção de grãos dos $F_{1}$ 's e das respectivas linhagens parentais.... 
RE S UMO

\title{
ANÁLISE DO POTENCIAL GENETICO DE CULTIVARES DE SOJA [Glycine $\max (\mathrm{L}$.$) Merrill] ATRAVES$ \\ DE CRUZAMENTOS DIALELICOS
}

\author{
Estefano Paludzyszyn Filho \\ José Branco de Miranda Filho
}

Linhagens provenientes de oito cultivares de soja, foram intercruzadas em esquema dialélico, com a finalidadé de avaliar o potencial genético das mesmas para utilização em programa de seleção recorrente, visando aumentos na produ ção de grãos.

A avaliação experimental das linhagens paren tais e respectivos $F_{1}$ 's, foi realizada em casa de vegetação. Obtiveram-seos valores do nūmero de dias para floração e matura ção e produção de grãos, os quais foram analisados segundo me todologias genético-estatísticas de Gardner \& Eberhart e de Griffing para avaliação do desempenho per se das linhagens e respectivas capacidades combinatórias.

As anālises evidenciaram a existência de dife renças entre as médias das 1 inhagens para todos os caracteres estudados, quanto ao valor intrínseco, ao potencial heterótí co, a capacidade combinátoria, a natureza dos efeitos de capa 
.xiv.

cidade geral de combinação e a diversidade genética. Além dis so, contribuíram para o conhecimento do tipo de ação gênica predominante no controle dos caracteres.

Para produção de grãos, as avaliações dos resul tados permitiram inferir sobre a superioridade das linhagens das cultivares no que diz respeito aos seguintes parânetros: comportamento per se (Bossier e $B R-5)$, combinação heterótica (Parană x IAS-4), efeito de capacidade geral de combinação (BR5 e Paranä), efeitos de linhagens (Bossier e $B R-5$ ) e heterose média de linhagem (IAS-4).

Adicionalmente, em vista da quantidade de infor mações obtidas, concluiu-se da utilidade da metodologia emprega da para anālise de médias em cruzamentos dialélicos de linha gens. 


\title{
ANALYSIS OF GENETIC POTENTIAL OF SOYBEAN [Glycine $\max (\mathrm{L}$.$) Merri11] CULTIVARS$ THROUGH DIALLEL CROSSES
}

\author{
Estefano Paludzyszy Filho \\ Josë Branco de Miranda Filho
}

\begin{abstract}
Lines from eight soybean cultivars were intercrossed in a diallel scheme to allow the evaluation of their genetic potential concerning yield improvement for use in a recurrent selection program.
\end{abstract}

Two genetic-statistical methods were utilized in the data analysis and allowed an evaluation of the behaviour of lines per se and their combining abilities.

The analysis indicated the existence of real differences among means of the lines for all caracters studied, time of flowering and maturity and yield in respect of intrinsic value, their heterotic potential, combining ability, nature of the general combining ability effect and genetic diversity. The analysis also provided contribution to the understanding of the predominant gene action present in the characters. 
From the yield evaluations, it was possible to conclude about cultivars superiorities in respect of the following parameters: per se value (Bossier and $B R-5$ ), heterotic combination (Paraná $x$ IAS-4), general combining ability effect $(B R-5$ and Parană), line effect (Bossier and $B R-5)$ and line heterotic mean $(I A S-4)$.

$$
\text { Additional1y, because of the large number of }
$$
informations obtained in this study, it was possible to conclude that the methodology of means analysis of homozygous lines utilized here was useful. 
1. INT RODUÇÃO

A soja (Glycine max (L.) Merr.) ao longo da ü tima dêcada, teve acentuada expansão do seu cultivo no Brasil. os resultados deste incremento foram obtidos em parte, pela o cupação de áreas cultivadas com outras espêcies e, principal mente, pela abertura de novas frentes agrícolas.

Ao lado dos benefícios causados a economia na cional pelo aumento da produção, a ampliação do uso das cultí vares existentes revelou nestas, aspectos negativos de adapta bilidade. Tal fato, aliado a crescente necessidade de novas cultivares, gerou estímulos ao desenvolvimento da pesquisa no país, notadamente na ärea de melhoramento. Nesta ärea, foram traçadas prioridades para fazerem frente a situação da crescen te expansão e objetivam:

1. Desenvolver cultivares apropriadas para utilização em re giões de baixas latitudes, situadas de modo geral, acima do 
parale1o $24^{\circ} \mathrm{S}$

2. Assegurar os níveis de rendimento das cultivares existen tes, através da incorporação de resistências a doenças e pragas, e melhoria de alguns caracteres agronômicos.

3. Desenvolver cultivares com níveis superiores derendimentos.

De modo geral, pesquisas envolvendo as duas pri meiras etapas estão sendo realizadas por diversas instituições. Os resultados destas pesquisas, são possíveis de serem avalia dos pelo número elevado de cultivares jā recomendadas no país.

Quanto a terceira etapa, o Centro Naciona 1 de Pesquisa de Soja (EMBRAPA-CNPSo), vem desenvolvendo metodolo gias que possibilitem a seleção de genótipos superiores nas ge raçö́es iniciais de populações segregantes.

Desta forma, ao lado do desenvolvimento de novas cultivares, são aperfeiçoadas técnicas experimentais que visam a obtenção de estimativas precisas e seguras dos inúmeros: ca racteres envolvidos na composição final da produção de grãos. Estas estimativas, quando analisadas através de métodos genétị co-estatísticos como os desenvolvidos por HAYMAN (1954a e b), GRIFFING (1956a e b) e GARDNER e EBERHART (1966) e outros, pos sibilitam, além do conhecimento das ações gênicas envolvidas no controle dos caracteres, a avaliação da capacidade dos genó tipos per se e quando em cruzamentos. Estas informações ser vem como elementos auxiliares aos melhoristas, frente a esco lha de método e critérios de melhorameñto. 
.3 .

o presente trabalho foi conduzido com a finali dade de avaliar o potencial genético de oito linhagens de so ja, utilizando-se a metodologia que tem por base a anālise da capacidade combinatória. 
2. REVISÃO DE LITERATURA

Nesta revisão serão abordados alguns tópicos, considerados de interesse para entendimento do presente estu do, realçados por opiniões e trabalhos de inúmeros pesquisado res. Os tópicos são: 1. 0 melhoramento e a genética quantitạ tiva; 2. base genética e aproveitamento desta para produção de grãos; 3. genética dos caracteres floração e maturação; 4. crụ zamentos dialélicos.

2.1. 0 melhoramento e a genética quantitativa

Os métodos de melhoramento de plantas desenvol vidos a partir de observações de inúmeros pesquisadores, embo ra mantendo os mesmos princỉpios, sofreram modificações com o avanço dos conhecimentos em áreas correlatas da ciência. Em autógamas, basicamente consistem na hibridação de um número pẹ queno de genótipos, seguidos de um dos processos de condução 
das populações segregantes durante vārias gerações, até a ob tenção de genótipos homozigotos para a maioria dos caracteres.

Embora os métodos tenham sido delineados com ba se na prática do melhoramento, eles tem se revelado eficazes na obtenção de genótipos superiores. Este aspecto é deduzido dos progressos havidos em muitas espécies, o que as tornou eco nomicamente cultivāveis. De modo geral, o sucesso desta meto dologia em plantas autógamas é devido, principalmente, ao fato dos trabalhos serem realizados com caracteres qualitativos ou com caracteres quantitativos que apresentam alta herdabilidade.

No entanto, com relação a caracteres cujo con tirole é efetuado por inúmeros genes, como a produção de grãos, altura de planta, etc, o progresso obtido pelo emprego dos mé todos tradicionais de melhoramento não são acentuados; tal o corre na soja, onde geralmente são observados pequenos progres sos por seleção (BRIM, 1973). A anālise de um suposto incre mento de $100 \mathrm{~kg} / \mathrm{ha}$, por ciclo de seleção, na produção de uma cultivar de soja foi realizada por FEHR (1978). Utilizando-se os métodos tradicionais, e com uma geração por ano, conclue o referido autor que seriam necessários 18 anos de trabalhos para a obtenção. de $300 \mathrm{~kg} / \mathrm{ha}$, a mais, em uma cultivar.

Segundo diversos autores, os progressos lentos obtidos, são, em parte, devido a pequena variabilidade existen te nos. cruzamentos realizados de forma tradicional. JENSEN (1970), observa que o emprego de um número reduzido de genótị pos, na.formação do conjunto gênico inicial, aliado as 1 imitações dos 
processos de seleção, são possíveis explicações dos baixos in crementos nos rendimentos das plantas.

o fato da utilização de um pequeno número de gẹ nótipos,para formação de populações segregantes, por melhoris tas de plantas autógamas, como em soja, contrasta amplamente com as técnicas utilizadas no melhoramento de plantas alógamas. Nestas, a preocupação maior dos melhoristas é com referência à elevação das frequências gênicas de alelos favoráveis, devido que, a formação de populações de ampla variabilidade não se a presenta como impedimento executivo ou funcional.

Basicamente, as teorias de seleção empregadas nos métodos tradicionais, visam identificar genótipos superio res. Nestes processos, porēm, aspectos como a estrutura genétí ca da população, as ações gênicas envolvidas no controle dos caracteres e a magnitude da variabilidade presente, normalmente não são considerados.

Com o advento das teorias e métodos da genética quantitativa, foram proporcionadas melhores condições para ob tenção dos caracteres desejāveis nas espécies agrícolas. Isto se deve, em parte, aos caracteres serem melhorados pela utiliza ção adequada de processos seletivos. A outra vantagem do em prego da genética quantitativa, como instrumento auxiliar na escolha do método de melhoramento a ser utilizado, deve-se ao fato de ser possível, além da caracterização das populações se gregantes quanto ao desempenho sob seleção, o conhecimento das ações gênicas envolvidas e da estrutura genética per se dos ge 
nótipos parentais dos cruzamentos. SPRAGUE (1966) observa que o conhecimento das ações gênicas envolvidas é o passo fundamen tal na tomada de decisão sobre a utilização do melhor método de hibridação, do melhoramento de populações e de seleção.

2.2. Base genética e aproveitamento desta para produção de grãos.

A produção de grãos em soja è uma ccaracterístị ca essencialmente quantitativa. Das ações gênicas envolvidas no controle deste caráter, JOHNSON e BERNARD (1963), após revi são dos trabalhos até então realizados, concluỉram: "a impor tância da variância genética aditiva parece de ser bem estabe lecida, ficando a dūvida sobre a relativa importância dos efe tos não aditivos".

BRIM (1973), em revisão dos trabalhos realizados após 1963, principalmente no sentido de evidenciar efeitos gê nicos não aditivos, resume em função das evidências presentes, embora, segundo o mesmo autor, não totalmente conclusivas "ser a variância genética a componente principal da variância geno típica para os caracteres de importância econômica em soja".

Estes relatos evidenciam a importância do ade quado aproveitamento das variâncias genéticas aditivas, embora, segundo BRIM (1973), não devam ser desprezadas ações gênicas do tipn aditivo $x$ aditivo ou as responsáveis por combinações hete rozigóticas favorāveis. 
MARTIN (1981), di.scute a importância dos efei tos epistāticos, ou das interações não alélicas presentes na he rança de caracteres quantitativos, de importância econômica em soja. Refere-se às implicações da epistáse quando da utiliza ção de alguns métodos de melhoramento. No caso de estimação dos efeitos de capacidade geral e específica de combinação, nenhum dos dois efeitos irá predizer o desempenho adequado da 1 inhagem per se, devido às correlações imperfeitas quando da presença de fatores epistáticos, conclue o referido autor.

A importância do conhecimento dos componentes da vàriância genética para o melhoramento de plantas, é traduzi da pela obtenção do parâmetro da herdabilidade para os caracte res. Segundo BRIM (1973), muitas decisões práticas nos progrạ mas de melhoramento são baseadas na magnitude da porção herdā vel do carāter.

$\mathrm{Na}$ soja, diversas estimativas do parâmetro da herdabilidade foram obtidas como resultados da avaliação de po pulações diferentes, do estāgio das gerações segregantes e da variação ambiental. Em revisão de literatura, BRIM (1973), a presentou valores compreendidos entre 0,65 a 0,91 e 0,75 a 0,94, respectivamente para nưmero de dias para floração e maturação. Para produção de grãos, segundo o mesmo autor, as variações fo ram de 0,03 (KWON e TORRIE, 1964) e 0,58 (BYTH et alii, 1969).

A presença de variações no parâmetro da herdabị lidade, para os diversos caracteres, pressupõe a necessidade de utilizar métodos adequados de melhoramento. 
Com o sentido do aproveitamento da ação gênica aditiva, envolvida em cruzamentos de soja, é que auto res como HANSON et alii (1967) e COMPTON (1968), discutem o a proveitamento de esquemas de seleção recorrente na soja, haja visto resultados promissores de tais métodos em plantas alóga mas, como o milho (SPRAGUE, 1967). Do ponto de vista genético, segundo KHADR e FREY (1965), não ocorrem impedimentos para ut lização de seleção recorrente em espécies autopolinizadas.

No entanto, a utilização plena de esquemas de sẹ leção recorrente é limitada na soja (BRIM, 1973). Tais limitações, se gundo o mesmo autor, são devidas às dificuldades naturais exis tentes para obtenção de níveis adequados de recombinantes dese jados. Como causas, podem ser citadas: dificuldades para reali zação de número suficiente de cruzamentos; pequeno número de sementes obtidas por cruzamento; tempo necessārio para avalia ção das progênies; 1 imitações nas metodologias empregadas para avaliações de progênies.

As mesmas limitações podem ser colocadas para a exploração de efeitos gênicos não aditivos, como heterose, em bora de pequena significância para a soja (BRIM, 1973).

Autores como JOHNSON e BERNARD (1963), FEHR (1978 e 1980), apontam técnicas comumente empregadas para obten ção de sementes híbridas. Diversos modos são apresentados, po rém, todos no sentido da obtenção de taxa superior de cruzamen to efetivamente realizados ou "pegos". Da mesma forma, BRIM et alii (1964), WEBER e FEHR (1967), BERNARD e JAYCOX (1969), 
sugerem técnicas que aumentam a eficiência dos cruzamentos a tificiais.

Porém, o que mais chamou a atenção dos melhoris tas de soja foi a descoberta por BRIM e YOUnG (1971) do cará ter macho-estéril, controlado por um par de genes recessivos $\left(\mathrm{ms}_{1} \mathrm{~ms}_{1}\right)$. Segundo os autores, $99 \%$ ou mais das sementes obti das das plantas macho-estéreis, eram devidas a cruzamentos natu rais. No entanto, ressalte-se, que embora a porcentagem fosse elevada, o número de sementes obtidas era pequeno por plantas, sendo em média de 40 (BURTON e BRIM, 1981). No entanto, deví dos a algumas limitações citadas anteriormente, esta média é superior às possíveis de serem obtidas por cruzamentos artifí ciais .

BRIM e STUBER (1973), relatam a maneira de ut lização do caráter macho-estéril para aplicação em. trabalhos de seleção recorrente em soja. Segundo, FEHR e ORTIZ (1975), o emprego do carāter macho-estéril em cruzamentos, permite a eliminação das polinizações manuais e reduz o tempo necessário para completar um ciclo de seleção.

Alguns resultados do emprego de seleção recor rente, através da utilização do caráter macho-estéril em soja, serão relatados a seguir, onde se evidencia a potencialidade da utilização do método.

KENWORTHY e BRIM (1979), relatam o primeiro re sultado com a utilização do método para rendimento de grãos. obtiveram os autores, após um ciclo, que consistiu de uma gera 
ção de cruzamentos, uma de autofecundação e a geração de tes te, um aumento de $16 \%$ no rendimento de grãos. Em consequên cia, aumentou em $15 \%$ o valor da proteína total.

BRIM e BURTON (1979), utilizando duas popula ções, I e II, subdivididas em sub-populações, A e B, obtiveram aumentos no teor de proteína, variando em função do núméro de ciclos de seleção. Assim, na sub-população IA, o teor aumen tou de $46,3 \%$ para $48,4 \%$ (seis ciclos); na IB, aumentou de $46,4 \%$ para $47,6 \%$ (4 ciclos), na IIA, aumentou de $42,8 \%$ para $46,1 \%$ ( 5 ciclos); e de $43,2 \%$ para $45,9 \%$ na população IIB com quatro cí clos de seleção.

BURTON e BRIM ( 1981 ), empregando o esquema de macho-estérilidade para percentagem de óleo nas sementes, obti veram um aumento não significativo de $444 \mathrm{~kg}$ para $460 \mathrm{~kg}$ de óleo por hectare. Para produção de grãos, os autores não èn contraram significâncias estatísticas.

A conclusão, a respeito da utilização do método de seleção recorrente, utilizando macho-esterilidade, dada por BURTON e BRIM (1981), indica ser o método eficiente para carac teres de alta herdabilidade ou quando apenas uma planta possa ser considerada como representativa de um genótipo; neste últị mo caso, o fato da utilização de pequenos espaços, em casa-de-vegetação ou no campo,para a obtenção de um ciclo em apenas um ano, é outro indicador da eficiência do método, segundo os autores.

Por outro lado, o aproveitamento de variâncias 
genéticas não aditivas, presentes nos cruzamentos em soja, (HANSON et alii, 1967) como possível causa dos efeitos de hete rose, apresenta-se, como anteriormente evidenciāo, de difícil utilização em larga escala. Na literatura, como resultados da avaliação de plantas individuais, na maioria dos casos, apare cem alguns trabalhos relatando efeitos de heterose para rendi mento de grãos. A seguir, alguns são apresentados.

VEATCH (1930), em cruzamentos envolvendo 16 cul tivares e/ou 1 inhagens, obteve um rendimento de $19,55 \%$ a mais em relação à média dos parentais. Heterose superior a esta, devido os resultados serem apresentados em relação ao parental superior, foi obtida por WEISS et $a$ li (1947). Dos ensaios de 17 cruzamentos, realizados em campo e em casa de vegetação, es tes autores obtiveram, respectivamente, $14 \%$ e $32 \%$ de heterose. LEFFEL e WEISS (1958), no entanto, em estudo de dialélico envolvendo 10 parentadis, obtiveram uma heterose média de 13,7\%, em relação à média do parental superior.

Com o objetivo de avaliar $F_{1}$ 's sob condições reais de campo, BRIM e COCKERHAM (1961), realizaram experimen tos em dois locais, em cada um dos dois anos. Obtiveram uma heterose média de $20 \%$ em relação ao parental superior. Signi ficativamente menor, porém, foi a heterose obtida por WEBER et alii (1970) que avaliaram 85 cruzamentos, em quatro anos, e obti veram uma heterose média de $13,4 \%$, em relação ao parental supe rior.

Em contraste, PASCHAL e WILCOX (1975), obtiveram 
uma heterose média de apenas $8 \%$, em relação ao parental supe rior. Ressalte-se que estes autores, com o objetivo de obter elevados rendimentos, devido a heterose, utilizaram combinações híbridas, envolvendo linhagens altamente adaptadas aos EüA, e in troduções presumídas de serem divergentes geneticamente em re 1 ação às 1 inhagens.

Face aos resultados apresentados, conclui-se que a exploração de vigor híbrido manifestado pela heterose po de ser considerada para aumentos da produção de grãos. Contu do, devido às dificuldades envolvidas na realização de cruzamen tos em larga escala, a obtenção de linhagens homozigotas, após vārias gerações de auto-fecundação, segundo PASCHAL e WILCox (1975), é ainda o melhor método de melhoramento.

2.3. Genética dos caracteres floração e maturação.

o tempo para floração e maturação em soja são geralmente considerados caracteres de herança quantitativa. Tal assertiva decorre das variações apresentadas. no número de dias, em ambos os caracteres, quando submetidas a variações ambi entais. KIIHL (1976), concluiu que sob condições de dias lon gos, o caráter dias para a floração é de herança quantitativa; porém, sob condições de dias curtos, o mesmo autor indica que o caráter floração tardia é controlado por poucos genes reces sivos. BERNARD (1971), identificou os genes $E_{1}$ e $E_{2}$ dominantes controlando dias para floração.e maturação na soja, Estes locos evidenciaramação gênìca: de dominância parcial para tempo de flo 
ração e maturação. BUZZEL (1971), identificou o gene E 3 domị nante, cujo efeito retarda o tempo para floração e maturação, sob condições de luz fluorescente.

Os relatos de literatura, quanto aos efeitos de heterose para ambos os caracteres,floração e maturação são a seguir descritos.

VEATCH (1930), em $15 \mathrm{~F}_{1}$ 's resultantes de cruza mentos, obteve que 11 floresceram tão tarde ou mais tarde que o parental superior. WEISS et alii (1947), obtiveram, para matu ração, que a média dos $F_{1}{ }^{\prime} s$ foi intermediária entre a média dos pais. LEFFEL e WEISS (1958), estudaram cruzamentos dialélicos de 10 parentais. Em média, os $F_{1}$ 's floresceram e maturaram precocemente em relação à média dos parentais. WEBER et alii (1970), obtiveram resultados variáveis para a heterose do nüme ro de dias para maturação, em relação à média dos parentais. Em média, os Fl's foram mais precoces para maturação, em relação ao parental superior.

\subsection{Cruzamentos dialé1icos}

Cruzamentos dialélicos se referem. a todos os cruzamentos possíveis de serem realizados, entre um grupo de $\underline{\text { n }} 1 \underline{\mathbf{i}}$ nhagens, variedades ou populações. Podem incluir, ou não, os tị pos parentais, bem como os cruzamentos recíprocos.

Atualmente, a metodologia de anālise dos cruza mentos em dialélico, é baseada, principalmente, nos trabalhos de três autores, a saber: HAYMAN (1954a e b), GRIFFING (1956a e b) 
GARDNER e EBERHART (1966).

A metodologia de HAYMAN (1954a e b), segundo o autor, é um poderoso meio de elucidar sistemas poligênicos. A sua utilização é indicada para linhagens puras, sendo, por is to, utilizada em plantas de auto-fertilização.

A anālise de GRIFFING (1956a e b), fundamentada num modelo estatístico, é amplamente utilizada em espécies aló gamas e autógamas. A metodologia é aplicável para quatro tị pos de tabelas dialélicas, com cálculos da análise da variân cia e estimação de efeitos de capacidade geral e específica de combinação, segundo dois modelos (fixo e aleatório).

A metodologia de GARDNER e EBERHART (1966), dis tingue-se das apresentadas por HAYMAN (1954a e b) e GRIFFING (1956a e b), basicamente por ser assentada em análise de compo nentes de médias de tabelas dialélicas. GARDNER e EBERHART (1966) indicam ser a metodologia,por eles apresentada, adequa da para anālise de cruzamentos dialélicos de variedades ou ra ças panmíticas. JOHNSON (1973) porém, utilizou esta metodolo gia para análise de cruzamentos dialélicos, envolvendo linhagens endógamas de variedades comerciais de milho. Uma ampla revisão sobre esta metodologia, (Gardner e Eberhart) é encon trada nos trabalhos de VENCOVSKY (1970) e MIRANDA FILHO (1974). Em soja, poucos relatos envolvendo cruzamentos diậ́1icos. são encontrados na literatura, a seguir resumidos. LEFFE e WEISS (1958), estudaram cruzamentos 
dialélicos envolvendo 10 cultivares analisados segundo as meto dologias de Griffing e Hayman. Os autores verificaram que os efeitos devidos à capacidade geral de combinação dos parentais estavam associados positivamente aos efeitos de dominância, bem como às médias parentais. Para rendimento de grãos e artura de plantas foram propostas as ações gênicas de dominância completa ou sobredominância. Ainda, os autores observaram que as metodolo gias utilizadas não foram conclusivas para distinção entre in terações alélicas e não alélicas nos genótipos.

WEBER et alii (1970) utilizando a metodologia de Griffing, avaliaram os caracteres rendimento de grãos e. ma turação. Significância foi obtida para os efeitos de capacida de geral (rendimento de grãos, maturação, altura da planta e teor de óleo) e específica (todos caracteres, exceto teor de óleo nos grãos).

PASCHAL e WILCOX (1975), em dialélico com 12 pạ rentais, avaliaram efeitos de capacidade geral e específica de combinação, segundo programa DIALL. Obtiveram significância pạ ra os efeitos de capacidade geral de todos os caracteres estu dados, enquanto para capacidade específica a significância foi obtida, apenas, para tamanho de sementes, maturação e altura de plantas.

SRIVASTAVA et alii (1978), analisando dialélico de. sete cultivares através da metodologia de Griffing, obtiveram para dias, quanto à floração e à maturação, uma substan 
cial variância dos efeitos de capacidade geral de combinação. Porém, para rendimento de grãos, a metodologia utilizada não permitiu avaliações conclusivas.

$$
\text { TOLEDO e KIIHL (1981), estudaram cruzamentos dia }
$$

lélicos de cinco cultivares para as características dias, para floração e número de folhas trifolioladas, segundo metoddlogia de Hayman e Griffing. Concluíram, os referidos dutores, da pro vável existência de um gene maior de efeito pleiotrópico no con trole dos dois caracteres estudados.

Outros trabalhos, envolvendo cruzamentos em dia lélico com soja, são citados no Plant Breeding Abstracts, como resumidos a seguir.

BHATADE et alii (1977), avaliaram seis parentais para produção de grãos, e outros quatro caracteres. Obtiveram significativas variâncias de c.g.c. paratodos os caracteres, exce to número de ramificações primárias, enquanto as variâncias de c.e.c. foram significativas para número de vagens por planta, número de ramificações primárias e altura de planta. JYANG (1975), em estudo de sete variedades de ciclo precoce e tardio, obteve que os $F_{1}$ 's foram intermediários entre as variedades parentais, pa ra número de dias para início da floração. Na análise, todas as variedades apresentaram dominância parcial para o caráter. KAWN et alii (1978), em avaliação de dez linhagens, por três outras, consideradas testadoras, obtiveram que em. nove dos dez caracteres estudados, houve o predominio da variân 
cia genética aditiva. KAWN et alïi (1981) avaliaram produção de grãos e três componentes deste caráter. Os resultados obti dos permitiram aos autores concluir que as variâncias de c.g.c. e c.e.c. foram significativas para todos os caracteres estudados. MILlER (1976), em estudo com dez parentais, obteve que os $F_{1}$ 's maturaram, pelo menós, dois dias após o parental mais tardio. SANTos (1978), em estudo com cinco parentais, obteve heteroses para 15 dos 26 caracteres estudados. A variância ge nética aditiva, segundo o mesmo autor, foi importante para todos os caracteres estudados, exceto comprimento de folhas. SENWA (1978), estudou o vigor de sementes sob diferentes temperaturas de embebição. Obteve que a variância genética não aditiva foi importante para o vigor de sementes, quando a embebição ocorreu a $5^{\circ} \mathrm{C}$.

Embora importantes, as informações obtidas das linhagens e das cultivares, especialmente para os melhoristas, as anālises de cruzamentos dialélicos em soja não se apre sentaram, de modo geral, conclusivas. Outra evidência desta re visão, é que as anālises de dialélicos foram basicamente reali zadas utilizando-se as metodologias de Griffing e Hayman. Em nenhum dos trabalhos citados, foi utilizada a metodologia pro posta por Gardner e Eberhart. 
3. MATERIAL

Para o presente estudo foram utilizadas uma sẹ rie de cultivares de soja. A escolha destas, baseou-se em cri térios de comportamento local ou regional quanto aos atributos da produtividade de grãos e caracteres agronômicos desejáveis. Os nomes das cultivares são apresentadas na mesma ordem das $1 \underline{i}$ nhagens citadas no transcorrer da apresentação deste trabalho.

$$
\text { A seguir é apresentada a descrição das cultiva }
$$
res quanto à genealogia, origem e algumas características de comportamento.

1. Pérola - obtida do cruzamento Hood x Industrial, realizado pelo IPAGRO-RS. Possue flor púrpura, pubescência cinza e bom vigor de sementes. Recomendada para plantio na região sul do país. Apresentoú rendi mento médio de grãos no Estado do Paraná de 3.185 kg/ha. GILIOLI et alii (1978). 
2. Paraná - obtida do cruzamento Hill x D52-810, realizado nos EUA. No Brasil, era identificada como linhagem pe la sigla N59-6800. Possue flor branca e pubescên cia cinza. E recomendada para cultivo em todos os estados da região Sul. Apresentou no Estado do Pa ranā, média de rendimento de grãos de $2.760 \mathrm{~kg} / \mathrm{ha}$. GILIOLI et alii (1978) e KASTER et alii (1979).

3. IAS-4 - Obtida de seleção realizada na linhagem $R-60-390$ (Hood x Jackson). Possue flor branca e pubescên cia cinza. Foi recomendada para o Estado do Rio Grande do Sul, aonde apresentou rendimento médio acima de $3.000 \mathrm{~kg} / \mathrm{ha}$. BONATO et ali (197.3).

4. Davis - Originada do cruzamento das linhagens $D 49-2573$ e N45-1497 realizado nos EUA. Possue flor branca e pubescência cinza. Foi recomendada para a ärea tradicional de cultivo. No Estado do Paraná, apre sentou um rendimento médio de grãos de $3.112 \mathrm{~kg} / \mathrm{ha}$. GILIOLI et alii (1978).

5. BR-5 - Resultante do cruzamento das cultivares Hill e Hood, realizado no IPEAS-RS, 1966. Quando linhagem era identificada por $P F-72278$. Possue flor pürpura e pubescência cinza. Foi recomendada para o Estạ do do Mato Grosso do Sul, aonde apresentou rendi mento médio de grãos de $2.650 \mathrm{~kg} / \mathrm{ha}$. DALL'AGNOL et $a$ Zii (1981). 
6. Bragg - Obtida do cruzamento da cultivar Jackson e da $1 \underline{\mathbf{i}}$ nhagem D49-2491, realizado nos EUA. No Brasil é recomendada para cultivo na região Sul. Possue flor branca e pubescência marrom. Apresentou no Estado do Paranā rendimento médio de $3.026 \mathrm{~kg} / \mathrm{ha}$. GILIOLI et alii (1978).

7. BR-1 - Originada do cruzamento realizado no IPEAS-RS, da cultivar Hill com uma seleção dentro da linhagem L-356. Possue flor branca e pubescência marrom. Foi recomendada para os estados do sul e Centro (MS). Apresentou no RS rendimento médio de grãos de $2.830 \mathrm{~kg} / \mathrm{ha}$. BONATO et alii (1979).

8. Bossier - originada de seleção dentro da cultivar Lee. Foi recomendada no Brasil para alguns estados das re giões Sul e Centro. Possue flor pürpura e pubes cência marrom. No Estado do Parană, apresentou ren dimento médio de $2.975 \mathrm{~kg} / \mathrm{ha}$. HYMOWITz et alii (1977) e GILIOLI et alii, (1978). 
4. METODOS

4.1. Planejamento e execução experimental

o presente estudo, é parte integrante do proje to "Seleção Recorrente e Desenvolvimento de Metodologia para o Melhoramento de Soja", do Centro Nacional de Pesquisa de Soja da Empresa Brasileira de Pesquisa Agropecuāria-EMBRAPA. 0 re ferido projeto foi iniciado em Londrina - Pr, (TOLEDo, J.F.F., comunicação pessoal). Deste modo, foram obtidos os dados refe rentes aos caracteres estudados neste trabalho.

\subsection{Preparação das 1 inhagens e cruzamentos}

Do Banco Ativo de Germoplasma, foram obtidas ạ mostras de sementes das cultivares previamente escolhidas. E tas sementes, permitiram a instalação e cultivo de quatro plan tas por genótipo, dispostas em dois vasos de cerâmica de $3 \mathrm{~kg}$, durante o inverno do ano de 1979. 
Na maturação, apenas uma planta foi colhida por cultivar, e cerca de 50 sementes obtidas após debulha manual das vagens. No mês de nov/dez, do mesmo ano, as sementes fo ram parceladamente emergidas em intervalos semanais, obtendose, pelo menos, um vaso com duas plantas por genótipo. No pẹ ríodo de floração das plantas foram realizados os cruzamentos, no sentido de se obterem cerca de 30 vagens com pelo menos uma semente, dos 28 cruzamentos possíveis. Cruzamentos récíprocos não foram realizados. Na fase de maturação das plantas, as va gens provenientes de cruzamentos foram colhidas, e as sementes armazenadas em câmara seca sob condições controladas de tempe ratura e umidade.

Em 1980, durante o mês de novembro, em laborató rio, as sementes provenientes dos cruzamentos e das linhagens parentais, foram postas em excesso a germinarem em "ger-box". As plântulas de mesmo tamanho e aparente vigor, foram trans plantadas duas a duas para vasos de cerâmica de $3 \mathrm{~kg}$ dispostos em casa-de-vegetação, aonde manteve-se sob controle somente a temperatura do dia $\left(26 \pm 2^{\circ} \mathrm{C}\right)$ durante todo o ciclo da planta. o delineamento utilizado para o experimento foi o látice $6 \times 6$ triplo duplicado, o qual permitiu a utilização de seis repeti ções em um compartimento da casa-de-vegetação.

\subsection{Caracteres observados}

Foram tomadas observações individuais nas plan tas para os seguintes caracteres: número de dias para início 
da floração, anotado a partir da data de transplante à abertú ra da primeira flor; número de dias para maturação, anotado quando cerca de $90 \%$ das vagens estavam maduras, e as plantas com folhas caỉdas; produção de grãos, anotado em gramas por planta, obtido após a debulha individual das vagens de cada planta e homogeneização da umidade das sementes.

4.4. Anālise da variância

Inicialmente, foram realizadas as anālises da variância segundo o delineamento utilizado, látice triplo du plicado. A baixa eficiência obtida com este delineamento, pa ra os três caracteres em estudo, indicou a não necessidade de ajuste dos dados; desta forma, as análises foram processadas segundo delineamento em blocos completos casualizados.

Para os caracteres número de dias para início da floração e número de dias para maturação, foi calculada a média de apenas uma parcela perdida; para produçãode grãos, foram calculadas, as médias de duas parcelas perdidas. Em ambos os ca sos, foram utilizadas as fórmulas apresentadas por GOMES (1977).

4.5. Anālise das tabelas dialélicas e estimação de parâme tros genéticos de médias, dos efeitos de c.g.c., e das variância de c.g.c. e c.e.c. associadas as linhagens

Foram preparadas tabelas dialélicas para os três caracteres em estudo, cựjas médias são resultan 
tes de seis repetições. A partir destas tabelas, segundo o mo delo fixo apresentado por GARDNER e EBERHART (1966), foram es timados os parâmetros genéticos das médias das iinhagens estü dadas, os quais indicam o potencial genético das próprias linhạ gens per se, e quando em cruzamentos. Além disto, o modelo per mite a verificação da heterose presente nos cruzamentos.

Por outro lado, a análise da variância das tabe las dialélicas, permite conhecer a significância estatística dos parâmetros genéticos.

0 modelo matemático das médias das tabelas dia -lélicas, devidamente adaptado quanto a simbologia é o seguinte:

$$
Y_{i j}=u+1 / 2\left(\ell_{i}+\ell_{j}\right)+\theta h_{i j}+\bar{e}_{i j}
$$

sendo:

$$
\begin{aligned}
& \mathrm{u}=\text { médias das } 1 \text { inhagens; } \\
& \ell_{i} \text { ou } \ell_{j}=\text { efeito "próprio de 1inhagem" da } 1 \underline{i} \\
& \text { nhagem } \mathbf{i} \text { ou } \mathbf{j} \text {; } \\
& h_{i j}=\text { "efeito de heterose" no } F_{1} \text { resultante do } \\
& \text { cruzamento das linhagens } i \text { e } j \text {; } \\
& \theta=\text { coeficiente dependente } \\
& \text { sendo } i=j \text { então } \theta=0 \\
& \mathbf{i} \neq \mathbf{j} \text { então } \theta=1 \text {; }
\end{aligned}
$$


$\bar{e}_{i j}=$ erro experimental ao nivel de médias, que $\bar{e}$ função do erro experimental $e_{i j} \sim N\left(0, \sigma^{2}\right)$. o "efeito de heterose" ( $\left.{ }_{i j}\right)$ é decomposto em: $\bar{h}=$ heterose média de todos $F_{1}$ 's;

$h_{i}$ ou $h_{j}=$ heterose própria da linhagem, contr $\underline{i}$ buída pela linhagem $i$ ou $j$ ao "efeito de heterose";

$s_{i j}=$ heterose específica ou capacidade especí fica de combinação entre as Iinhagens i e j.

Assim, o modelo matemático completo das médias resul ta na forma:

$$
Y_{i j}=u+1 / 2\left(l_{i}+l_{j}\right)+\theta\left(\bar{h}+h_{i}+h_{j}+s_{i j}\right)+\bar{e}_{i j}
$$


o quadro da anālise da variância é o seguinte:

\begin{tabular}{|c|c|c|c|}
\hline F.V. & GL & QM & $\bar{F}$ \\
\hline Tratamentos ${ }^{+}$ & $(35)$ & $\mathrm{Q}_{1}$ & $\mathrm{Q}_{1} / \mathrm{Q}_{7}$ \\
\hline Linhagens & 7 & $\mathrm{Q}_{2}$ & $\mathrm{Q}_{2} / \mathrm{Q}_{7}$ \\
\hline Heterose & $(28)$ & $Q_{3}$ & $\mathrm{Q}_{3} / \mathrm{Q}_{7}$ \\
\hline heterose média & 1 & $Q_{4}$ & $Q_{4} / Q_{7}$ \\
\hline heterose de linhagens & 7 & $Q_{5}$ & $\mathrm{Q}_{5} / \mathrm{Q}_{7}$ \\
\hline heterose específica & 20 & $Q_{6}$ & $Q_{6} / Q_{7}$ \\
\hline Erro Médio ${ }^{++}$ & 174 & $\mathrm{Q}_{7}$ & \\
\hline $\operatorname{cgc}^{+++}$ & 7 & $\mathrm{Q}_{8}$ & $\mathrm{Q}_{8} / \mathrm{Q}_{7}$ \\
\hline
\end{tabular}

$+\quad$ tratamentos incluem as linhagens parentais e os $F_{1}$ 's resul tantes dos cruzamentos.

++ obtido a partir do quadrado médio do erro experimental da variância de blocos completos casualizados, dividido pelo número de repetições - para produção de grãos - considerar $173 \mathrm{GL}$.

+++ quadrados médios e significância estatística da capacidade geral de combinação (c.g.c.) das linhagens, obtido segundo GRIFFING (1956), método experimental 4, modelo I. 
As estimativas dos parâmetros genéticos compo nentes das médias das linhagens ou dos $F_{l}$ 's, as variâncias das estimativas e as somas de quadrados da anālise da variância do modelo de GARDNER e EBERHART (1966), foram calculadas segundo as fórmulas apresentadas por VENCOVSKY (1969), adaptadas em sua simbologia para o presente estudo, e apresentadas como segue:

a - estimativas dos parâmetros:

$\hat{\mathrm{u}}=\frac{\mathrm{L}}{\mathrm{n}} ;$

$\hat{\ell}_{i}=\mathrm{L}_{i}-\frac{\mathrm{L}}{\mathrm{n}} ;$

$\hat{\mathrm{h}}_{i j}=\overline{\mathrm{h}}+\hat{\mathrm{h}}_{i}+\hat{\mathrm{h}}_{\mathrm{j}}+\hat{\mathrm{s}}_{i j}=\mathrm{c}_{i j}-\frac{\mathrm{L}_{i}+\mathrm{L}_{j}}{2}$;

$\hat{\mathrm{h}}=\frac{2 C \ldots}{\mathrm{n}(\mathrm{n}-1)}-\frac{\mathrm{L} \cdot}{\mathrm{n}} ;$

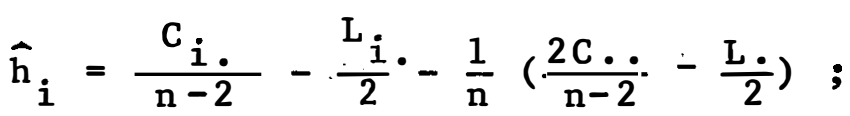

$\hat{s}_{i j}=c_{i j}+\frac{2 C \ldots}{(n-1)(n-2)}-\frac{c_{i}+c_{j \cdot}}{n-2} ;$

onde:

$$
\begin{aligned}
\text { L. = } & \text { soma das médias das linhagens; } \\
C_{.}= & \text {soma das médias de todos os cruzamentos; } \\
C_{i}= & \text { soma das médias dos cruzamentos em que particí } \\
& \text { pa a linhagem i; }
\end{aligned}
$$




$$
\begin{aligned}
\mathrm{C}_{\mathbf{j}}= & \text { soma das médias dos cruzamentos em que participa a } \\
& 1 \text { inhagem } \mathrm{j}
\end{aligned}
$$

b - variâncias das estimativas:

$\operatorname{var} \hat{\mathrm{u}}=\frac{\sigma^{2}}{\mathrm{n}}$

$\operatorname{var} \hat{l}_{i}=\frac{(n-1)}{n} \sigma^{2}$

$\operatorname{var} \overline{\mathrm{h}}=\frac{\mathrm{n}-1}{\mathrm{n}(\mathrm{n}-1)} \sigma^{2}$

$\operatorname{var} \hat{\mathrm{h}}_{i}=\frac{(\mathrm{n}-1)(\mathrm{n}+2)}{4 \mathrm{n}(\mathrm{n}-2)} \sigma^{2}$

Onde $\sigma^{2}$ é a variância residual ao nível de médias.

$$
\text { c - sómas de quadrados da anālise da variância: }
$$

$S \cdot Q \cdot$ tratamentos $=\sum_{i=j} L_{i}^{2}+\sum_{i<j} \quad C_{i j}{ }^{2}-\frac{2 T^{2}}{n(n+1)}$

$S \cdot Q \cdot 1$ inhagens $=\frac{1}{n+2}\left[\sum_{i=1}^{n}\left(2 L_{i}+C_{i .}\right)^{2}-\frac{4 T^{2}}{n}\right]$

$S \cdot Q \cdot$ heterose $=\sum_{i=1}^{n} L_{i}^{2}+\sum_{i<j} C_{i j}{ }^{2}+\frac{1}{n+2}\left[\frac{2 T^{2}}{n+1}-\sum_{i=1}^{n}\left(2 L_{i}+C_{i} j^{2}\right]\right.$

$S \cdot Q \cdot$ heterose média $=\frac{1}{n}\left(\frac{2 C^{2} \cdots}{n-1}+L \cdot^{2}-\frac{2 T^{2}}{n+\frac{1}{1}}\right)$ 
.30 .

S.Q. heterose da linhagem $=\frac{1}{(n-2)(n+2)} \sum_{i=j}^{n}\left[(n-2) L_{i}-\right.$ $\left.-2 c_{i .}\right]^{2}-\frac{4}{n}\left(\frac{C^{2} \cdots}{n-2}-\frac{T^{2}}{n+2}\right)-\frac{L^{2}}{n}$

S.Q. heterose específica $=\sum_{i<j} \quad C^{2}{ }_{i j}-\frac{1}{n-2}\left(\sum_{i=j}^{n} C_{i}^{2}-\frac{2 C^{2} \cdots}{n-1}\right)$

Onde:

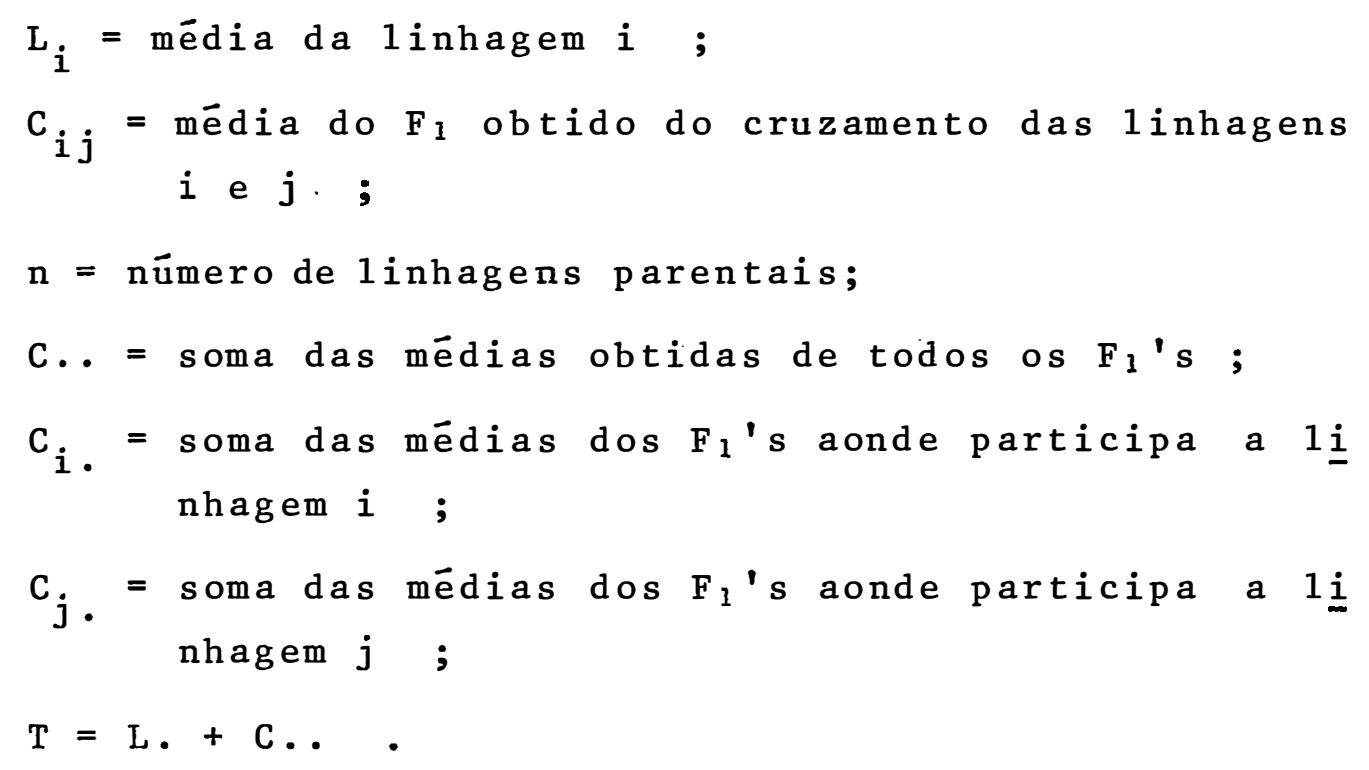


As somas de quadrados para as estimativas dos $\underline{e}$ feitos de capacidade geral de combinação (c.g.c.), foram obti das segundo GRIFFING (1956) método experimental 4, modelo I, como segue:

$$
\mathrm{S} \cdot \mathrm{Q} \cdot(\mathrm{c} \cdot \mathrm{g} \cdot \mathrm{c} .)=\frac{1}{\mathrm{n}-2} \sum_{\mathrm{i}} \quad \mathrm{c}^{2}{ }_{i} \cdot-\frac{4}{\mathrm{n}(\mathrm{n}-2)} \mathrm{c}^{2} \ldots
$$

$$
\begin{aligned}
& \text { onde: } \quad C_{i .}=\sum_{i \neq j} \quad C_{i j} \\
& C \ldots=\sum_{i<j} C_{i j}
\end{aligned}
$$

As estimativas dos efeitos de capacidade geral de combinação das linhagens, foram obtidas segundo GARDNER e EBERHART (1966) como segue:

$$
\hat{g}_{i}=\frac{1}{2} \hat{\ell}_{i}+\hat{h}_{i}
$$

As variâncias entre as diferenças $\left(\hat{g}_{i}-\hat{g}_{j}\right)$ das estimativas dos efeitos de capacidade geral de combinação ( $\left.\hat{g}_{i}\right)$, foram obtidas, segundo GRIFFING (1956) como segue:

$$
\operatorname{var}\left(\hat{g}_{i}-\hat{g}_{j}\right)=\frac{2}{n-2} \sigma^{2}
$$

sendo: $\quad n=$ número de linhagens parentais;

$$
\sigma_{i}^{2}=\text { variância residual ao nível de médias. }
$$


As variâncias das estimativas dos efeitos de ca pacidade geral de combinação, associadas a cada 1 inhagem $\left(\sigma^{2} \vec{g}_{i}\right)_{\gamma}$ e as variâncias das estimativas da média dos efeitos de capaci dade específica de combinação, associada a cada linhagem ( $\sigma^{2} \hat{s}_{i}$ ); foram obtidas segundo GRIFFING (1956), respectivamente como seguem:

$$
\begin{aligned}
& \sigma^{2} \hat{g}_{i}=\left(\hat{g}_{i}\right)^{2}-\frac{n-1}{n(n-2)} \sigma^{2} ; \\
& \sigma^{2} \hat{s}_{i}=\frac{1}{n-2} \sum_{i \neq j} \sum_{j} \hat{s}_{i j}-\frac{n-1}{n-2} \sigma^{2}
\end{aligned}
$$

sendo: $n=$ número de linhagens parentais;

$\sigma^{2}=$ variância residual ao nível de médias.

4.6. Cảlculo das heteroses médias das linhagens

Foram obtidas as heteroses médias das 1 inhagens quando em cruzamentos para os três caracteres em estudo. Para tanto, utilizou-se da seguinte fórmula:

$$
\overline{\mathrm{h}}_{i}=\overline{\mathrm{h}}+\frac{\mathrm{n}-2}{\mathrm{n}-1} \mathrm{~h}_{\mathrm{i}} \text {, }
$$

a qual pode ser expressa em porcentagem da média dos pais, como segue:

$$
\overline{\mathrm{h}}_{i}(\%)=\overline{\mathrm{h}}_{i} / \overline{\mathrm{L}},
$$


sendo:

$$
\begin{aligned}
& \overline{\mathrm{h}}_{i}=\text { heterose média da } 1 \text { inhagem } i ; \\
& \overline{\mathrm{h}}=\text { heterose média de todos os cruzamentos; } \\
& \mathrm{h}_{i}=\text { efeito de heterose da } 1 \text { inhagem } i ; \\
& \mathrm{n}=\text { número de linhagens parentais; } \\
& \overline{\mathrm{L}}=\left[(n-1) \mathrm{L}_{i}+\sum_{j \neq i} L_{j}\right] / 2(n-1)
\end{aligned}
$$

4.7. Partição dos efeitos das estimativas da capacidade ge ral de combinação.

Foram realizados para os três caracteres em es tudo, a decomposição dos efeitos que compõem as estimativas da capacidade geral de combinação $\left(\hat{g}_{i}\right)$, e são espressos em formas de porcentagens. Para separação das mesmos, foi utilizada a e quação apresentada por GARDNER e EBERHART (1966):

$$
\hat{\mathrm{g}}_{i}=1 / 2 \hat{l}_{i}+\hat{\mathrm{h}}_{i}
$$

4.8. Covariâncias entre estimativas dos efeitos $\hat{l}_{i}$ e $\hat{h}_{i}$

Foram calculadas as estimativas das covariâncias entre as estimativas dos efeitos de linhagem ( $\hat{l}_{i}$ ) e efeitos de heterose própria da 1 inhagem $\left(\hat{h}_{i}\right)$, para os três caracteres em estudo, segundo a fórmula:

$$
\operatorname{covv}_{\ell h}=\frac{1}{n-1} \sum \hat{\ell}_{i} \hat{h}_{i}
$$


4.9. Correlação entre Fl's e respectivas médias das 1 inhạ gens parentais

Foram obtidos os coeficientes de correlação sim ples ( $r$ ) entre as médias das 1 inhagens parentais envolvidas nos cruzamentos dialélicos e a média dos $F_{1}^{\prime}$ 's resultantes dos cru zamentos para os três caracteres em estudo, como segue:

$$
\hat{r}=\hat{\operatorname{Cov}}_{L C} / \hat{\sigma}_{L} \hat{\sigma}_{C},{ }^{\beta} \text { sendo: }
$$

$$
\begin{aligned}
& r=\text { coeficiente de correlação; } \\
& \hat{\sigma}^{2} \text { L }=\text { estimativa da variância entre as médias das duas } 1 \underline{i} \\
& \text { nhagens parentais de cada cruzamento; } \\
& \hat{\sigma}^{2} \mathrm{C}=\text { estimativa da variância entre as médias dos cruza } \\
& \hat{C o v}_{L C}=\text { estimativa da covariância entre as médias das duas } \\
& \text { linhagens parentais e as médias dos hỉbridos. }
\end{aligned}
$$




\section{RESULTADOS}

\subsection{Resultados preliminares}

Os valores obtidos com a anālise da variância para os três caracteres em estudo, demonstraram à baixa ef $\underline{i}$ ciência do delineamento látice empregado. As respectivas ef ciências obtidas foram de $104,62 \%, 101,20 \%$ e $102,50 \%$ para os caracteres número de dias para inîcio da floração, nümero de dias para maturação e produção de grãos (gramas por planta). De vido a baixa eficiência do delineamento em látice, as anālises foram realizadas segundo o delineamento emblocos casualizados.

$$
\text { Os valores e respectivas significâncias dos qua }
$$
drados médios, conjuntamente aos coeficientes de variação para os três caracteres em estudo, são apresentados na Tabela 1 . Os quadrados médios apresentaram significância estatística a nível de $1 \%$ de probabilidade para a fonte de variação tratamentos ( 1 inhagens parentais e $F_{l}^{\prime} s$ ) para os três caracteres em estudo. 
Os coeficientes de variação foram, respectivamen te $\operatorname{de}_{4} 4,49 \%, 4,41 \%$ e $15,25 \%$ para floração, maturação e produção de grãos e foram considerados comuns dentro dos limites aceita veis na experimentação agronômica.

Na Tabela 2, são apresentadas as médias de seis repetições do nümero de dias para início da floração das 8 linhagens parentais e respectivos $F_{1}{ }^{\prime} s$. As 1 inzagens das cultivares IAS-4 e Bossier foram respectivamente a mais preco ce $\left(L_{3}=26,25\right.$ dias) e a mais tardia ( $L_{8}=42,42$ dias $)$ para início da floração e o $F_{1}$ mais tardio $\left(C_{57}=37,67\right.$ dias $)$ para o mesmo caráter, foi resultante do cruzamento das 1 inhagens das cultivares $B R-5$ e $B R-1$.

Na Tabela 3, são apresentadas as médias do núme ro de dias para maturação, respectivamente das 1inhagens e $F_{1}$ 's. As 1 inhagens das cultivares Paraná e Bragg foram respec tivamente a mais precoce $\left(\mathrm{L}_{2}=104,17\right.$ dias $)$ a mais tardia $\left(L_{6}=129,67 \mathrm{dias}\right) \cdot \mathrm{s}_{1} \mathrm{~F}_{1} \mathrm{~s}$, mais precoce $\left(\mathrm{C}_{12}=109,67 \mathrm{dias}\right)$ e o mais tardio $\left(C_{78}=138,33\right.$ dias $)$, foram resultantes dos cru zamentos das 1 inhagens das cultivares, respectivamente, Pérola com Paraná e $B R-1$ com Bossier.

$\mathrm{Na}$ Tabela 4 , são apresentadas as médias resul tantes de seis repetições do caráter produção de grãos (g/planta). A 1 inhagem da cultivar IAS-4 ( $\mathrm{L}_{3}=17,12 \mathrm{~g} / \mathrm{p} 1$ anta) e a 1 inha gem da cultivar Bossier ( $\left.\mathrm{L}_{8}=31,40 \mathrm{~g} / \mathrm{p} 1 \mathrm{anta}\right)$ foram respectiva mente, a de menor e de maior produção de grãos. Os $\mathrm{F}_{1}{ }^{1} \mathrm{~s}$ variaram de $\left(\mathrm{C}_{3}{ }_{7}=\right.$ 20,98 até $\mathrm{C}_{25}=31,22 \mathrm{~g} / \mathrm{p} 1$ anta, respectivamente provenientes 
dos cruzamentos das linhagens das cultivares IAS-4 com $B R-1$ e Paraná com $B R-5$.

\subsection{Resultados das análises das tabelas dialélicas}

$$
\text { Na Tabela 5, são apresentados os valores e sig }
$$

ficâncias dos quadrados médios, resultantes da análise da variân cia da tabela dialélica, segundo a metodologia de GARDNER e EBERHART (1966), e os quadrados médios e respectivas significân cias dos efeitos de capacidade geral de combinação (c.g.c.) ob tidos, segundo GRIFFING (1956), para os três caracteres em es tu do .

Para ambos os modelos estudados, todos os quadra dos médios componentes da tabela 5, apresentaram significân cias ao nível de $1 \%$ de probabilidade.

5.3. Resultados das estimativas dos componentes de médias

Nas Tabelas 6,7 e 8 , são apresentadas as esti mativas dos parâmetros da heterose dos cruzamentos $\left(\bar{h}_{i j}\right)$ e da heterose específica ou capacidade específica de combinação $\left(\hat{s}_{i j}\right)$. Também, estão incluídas a média das linhagens parentais (û) a heterose média dos cruzamentos $(\overline{\bar{h}})$ e erros padrões. As referi das tabelas, são, respectivamente para os caracteres número de dias para início da floração, número de dias para maturação e produção de grãos.

As estimativas das médias das. 1 inhagens paren tais obtidas foram de: $\widehat{u}=34,959$ dias para inícioda floração; 
$\widehat{\mathrm{u}}=120,666$ dias para maturação; $\widehat{u}=24,249 \mathrm{~g} / \mathrm{p} 1$ anta para pro dução de grãos.

Quanto aos componentes da heterose (Tabelas 6, 7 e 8) excessao a heterose das 1 inhagens, obteve-se para o ca ráter número de dias para início da floração, uma heterose mé dia de $\hat{\bar{h}}=-2,117$ dias e para a heterose dos cruzamentos $\left(\overline{\bar{h}}_{\mathbf{i j}}\right)$, obteve-se uma vał̧iação de $\hat{h}_{78}=-8,33$ a $\hat{h}_{23}=1,29$ dias. Para a heterose específica $\left(\hat{s}_{i j}\right.$ ) a variação obtida foi de $\hat{s}_{78}=$ $-2,04$ a $\hat{s}_{68}=1,43$ dias; para o caráter número de dias para ma turação, obteve-se uma heterose média de $\overline{\bar{h}}=4,10$ dias, sendo que a heterose dos cruzamentos $\left(\widehat{h}_{i j}\right)$ variou de $\hat{h}_{15}=-3,50$ a $\hat{\mathrm{h}}_{27}=14,70$ dias, enquanto para a heterose específica ( $\left.\hat{\mathrm{s}}_{\mathbf{i j}}\right)$, obteve-se uma variação de $\hat{s}_{38}=-6,21$ a $\hat{s}_{18}=4,38$ dias; para o caráter produção de grãos, obteve-se uma heterose média de $\hat{\overline{\mathrm{h}}}=2,49 \mathrm{~g} / \mathrm{p} 1 \mathrm{anta}$, sendo que para a heterose dos cruzamentos $\left(\hat{\mathrm{h}}_{\mathrm{ij}}\right)$, obteve-se uma variação de $\hat{\mathrm{h}}_{78}=-7,16$ a $\hat{\mathrm{h}}_{35}=7,68 \mathrm{~g} /$ planta. Para a heterose específica, a variação obtida foi de $\hat{\mathrm{s}}_{46}=-3,85$ a $\hat{\mathrm{s}}_{67}=5,75 \mathrm{~g} / \mathrm{p} 1 \mathrm{anta}$. Na Tabela 9, para produção de grãos, as heteroses são apresentadas em forma de porcenta gens sobre a média dos parentais e parental superior.

Da somá de quadrado total para produção de grãos, $37,83 \%$ foi devida aos efeitos de 1 inhagens e $62,17 \%$ a heterose total, sendo,esta ūltima, distribuída para os seus componentes nas seguintes proporções: 13,50\% a heterose média, $27,75 \%$ a he terose de linhagens e $58,75 \%$ a heterose específica. Para flo ração, a soma de quadrados foi distribuída como segue-se: $74,05 \%$ 
para 1 inhagens, $25,95 \%$ para heterose total, e desta, $27,19 \%$ pa ra heterose média, $53,43 \%$ para heterose de 1 inhagens e $19,38 \%$ para heterose específica. Para maturação, a soma de quadrados teve uma semelhança a distribuição da floração, sendo: 79,13\% para 1 inhagens, $20,86 \%$ para heterose total, da qua $121,71 \%$ foi atribuída a heterose média, $34,80 \%$ para heterose de 1 inhagens e $43,49 \%$ para heterose específica.

5.4. Resultados das heteroses médias das linhagens

Na Tabela 10 , são apresentadas as heteroses mé dias das linhagens parentais quando em cruzamentos dialélicos para os três caracteres em estudo. Para floração, a maior esti mativa da heterose média de linhagém $\left(\hat{\bar{h}}_{i}\right)$ foi da linhagem da cul tivar IAS-4 com $\widehat{\bar{h}}_{3}=-0,5594$ e a menor, da linhagem da culti var Bossier com $\hat{\bar{h}}_{8}=-5,6550$ dias; para maturação, a maior esti mativa da heterose média de linhagem foi obtida com a linhagem da cultivar $B R-1$ com $\widehat{\bar{h}}_{7}=9,9064$ dias, e a menor, da 1 inhagem da cultivar Bragg $\operatorname{com} \widehat{\bar{h}}_{6}=1,6135$ dias; para produção de grãos a maior estimativa da heterose média de linhagem, foi da 1 inhagem da cultivar IAS-4 $\operatorname{com} \widehat{\bar{h}}_{3}=5,2130$ (g/planta) e a menor esti mativa, foi da linhagem da cultivar Bossier com $\hat{\bar{h}}_{8}=-0,7227(\mathrm{~g} /$ planta), respectivamente, $24,54 \%$ e $-2,05 \%$. 
5.5. Resultados das estimativas dos componentes de médias, dos effeitos de capacidade geral de combinação e das va riâncias associadas aos efeitos de capacidade geral e específica das 1 inhagens.

As Tabelas 11,12 e 13, respectivamente para os caracteres, nūmero de dias para início dafloração, número de dias para maturação e produção de grãos ( $/$ /planta), contém as êsti mativas dos seguintes parâmetros: do efeito da 1 inhagem ( $\hat{l}_{i}$ ), do efeito da heterose das linhagens $\left(\hat{h}_{i}\right)$ e do efeito da capaci dade geral de combinação além das estimativas das variâncias da capacidades geral $\left(\hat{\sigma}^{2} \hat{g}_{i}\right)$ e específica $\left(\hat{\sigma}^{2} \hat{s}_{i}\right)$ das linhagens.

As estimativas dos efeitos de linhagens $\left(\hat{\ell}_{\hat{i}}\right)$, p a ra início da fioração, variaram de $\hat{l}_{3}=-8,7087$ a $\hat{l}_{8}=7,4613$ dias; para maturação obteve-se uma variação de $\hat{\ell}_{2}=-16,4962$ a $\hat{l}_{6}=9,0038$ dias; para produção de grãos a variação foi de $\hat{l}_{3}=-7,1287$ a $\hat{l}_{8}=7,1513 \mathrm{~g} / \mathrm{p} 1 \mathrm{anta}$.

As estimativas da heterose das linhagens $\left(\hat{\mathrm{h}}_{i}\right)$, para início da floração, variaram de $\hat{\mathrm{h}}_{8}=-4,1281$ a $\hat{\mathrm{h}}_{3}=1,8168$ dias; para maturação, a variação obtida foi de $\hat{h}_{6}=-2,9018$ a $\hat{\mathrm{h}}_{7}=6,7731$ dias; para produção de grãos, a variação em gramas por planta foi de $\hat{h}_{8}=-3,7433$ a $\widehat{h}_{3}=3,1777$.

Quanto ao efeito de capacidade geral de combina ção $\left(\hat{g}_{i}\right)$, as estimativas obtidas para início de floração em nümero de dias, variaram de $\hat{g}_{3}=-2,5375$ a $\hat{g}_{7}=1,7696$; $\quad$ para maturação, a variação obtida foi de $\hat{g}_{2}=-8,6183$ a $\hat{g}_{7}=10,4801$; 
para produção de grãos as maiores estimativas obtidas foram $\hat{\mathrm{g}}_{2}=0,9780$ e $\hat{\mathrm{g}}_{5}=3,5250$.

As estimativas das variâncias dos efeitos de ca pacidade geral $\left(\hat{\sigma}^{2} \hat{g}_{i}\right)$ e específica $\left(\hat{\sigma}^{2} \hat{s}_{i}\right)$ associadas às 1 inha gens, apresentaram uma variação em função da 1 inhagem parental. A maior estimativa da variância do efeito de capacidade geral de combinação foi $\hat{\sigma}^{2} \hat{g}_{3}=6,3845$, e a maior estimativa da variân cia do efeito específico de combinação obtido foi $\hat{\sigma}^{2} \hat{s}_{7}=1,1077$ para o caráter número de dias para início da floração; para matụ ração, a maior estimativa da variância do efeito geral de com binação obtida foi $\hat{\sigma}^{2} \hat{g}_{7}=109,1067$ e a maior estimativa da vâ riância do efeito de capacidade específica de combinação foi $\hat{\sigma}^{2} \hat{s}_{1}=11,2752$; para produção de grãos, a maior estimativa da vạ riância dos efeitos de capacidade geral de combinação foi $\hat{\sigma}^{2} \hat{g}_{5}$ $=12,0935$ e a maior estimativa da variância do efeito específ $\underline{i}$ co de combinação $\hat{\sigma}^{2} \hat{s}_{7}=10,9077$.

As estimativas negativas, das variâncias dos e feitos da capacidade geral e específica, associadas as linha gens das Tabelas 11, 12 e 13, são consideradas de valor zero.

5.6. Resultados da partição dos efeitos de c.g.c.

A partição dos componentes das estimativas dos efeitos da capacidade geral de combinação ( $\left.\hat{g}_{i}\right)$ das 1 inhagens, para os três caracteres, são apresentados na Tabela 14 . Em por centagens, foram separados os componentes $\hat{l}_{i}=$ efeito de 1 inha gens e $\hat{\mathrm{h}}_{i}=$ heterose das 1 inhagens. Tais efeitos, constituem 
o efeito total da capacidade geral de combinação da linhagem, $\left(\hat{\mathrm{g}}_{i}\right)$, apresentado por GARDNER e EBERHART (1966), como segue: $\hat{g}_{i}=1 / 2 \hat{l}_{i}+\hat{h}_{i}$.

Para produção de grãos, exemplificando, o efeito de linhagem $\left(\hat{\ell}_{i}\right)$ e o efeito da heterose da linhagem $\left(\hat{\mathrm{h}}_{i}\right)$ na capa cidade geral de combinação $\left(\hat{g}_{i}\right)$, temos para a linhagem da cul tivar $B R-5$ suma capacidade geral de combinação $\hat{g}_{5}=3,5251$. Des ta estimativa, $69,8 \%$ são devidos a metade do efeito da própria linhagem $\left(\hat{l}_{5}=4,9213 \mathrm{~g} / \mathrm{planta}\right) ;$ o restante $30,2 \%$ são devidos ao efeito da heterose da 1 inhagem $\left(\widehat{h}_{5}=1,0644 \mathrm{~g} / \mathrm{p} 1\right.$ anta $)$.

5.7. Resultados da covariância entre estimativas dos efei tos de $\hat{l}_{i}$ e $\hat{h}_{i}$

Foram obtidos os valores das covariâncias entre os efeitos fixos das linhagens $\left(\hat{l}_{i}\right)$ e a heterose das 1 inhagens $\left(\hat{h}_{i}\right)$. Para número de dias para início da floração, o valor foi Côvế $\hat{h}=-7,8471$; para maturação, em número de dias, obteve-se o valor Côvêh $=4,5502$; para produção de grãos, o valor ob tido foi covế $\hat{h}=-7,1525$ (g/planta).

5.8. Resultados das correlações entre as médias dos Fi's e as médias das respectivas linhagens parentais.

Foram obtidos os coeficientes de correlação sim ples ( $r$ ) entre as médias dos $F_{1}$ 's e as médias das respectivas linhagens parentais para os três caracteres estudados. Para 
.43.

floração, obteve-se um coeficiente de correlação $r=0,719$; pạ ra maturação, obteve-se $r=0,791$. Para ambos os caracteres, os coeficientes de correlação foram significativos a nível de $1 \%$ de probabilidade. Para produção de grãos, obteve-se um coe ficiente de correlação $r=0,259$, não significativo a nível de $5 \%$ de probabilidade. Nas figuras 1,2 e 3, são apresentadas as respectivas regressões 1 ineares. 
6. DISCUSSÃO

6.1. Avaliação das 1inhagens, heteroses e das correlações

A obtenção de rendimentos superiores nos genótị pos de soja, tem sido objetivo constante nos programas de melho ramento. Para tanto, alēm dos métodos tradicionais, processos alternativos, como o aproveitamento do vigor de hỉbrido e em prego de seleção recorrente, são estudados.

As cultivares de soja, neste estudo representa das por linhagens, foram selecionadas basicamente para fins de emprego em programas de seleção recorrente delineado, para au mentos na produção de grãos. Entretanto, além do rendimento de grãos, foram incluídos, neste estudo, observações e anālises referentes aos caracteres número de dias para início da flora ção e número de dias para a maturação, considerados parâmetros auxiliares nos processos de seleção. 
As interpretações dadas aos resultados obtidos neste estudo, são dirigidas visando o emprego das mesmas como e lementos auxiliares no programa de melhoramento delineado. Po rém, são importantes as ressalvas sobre a condição experimental de um único ambiente e da representatividade das linhagens em relação às respectivas cultivares. Por outro lado, a utiliza ção de modelo fixo para todas as anālises estratísticas, condicio na a aplicabilidade dos resultados apenas ao conjunto estudado.

A significância estatística encontrada na análi se da variância, realizada para os três caracteres, indicou a existência de diferenças reais entre os tratamentos (médias das linhagens parentais e FI's).

Considerando direções desejadas no melhoramento da soja como o retardamento do início da floração, a melhor mé dia obtida foi da linhagem da cultivar Bossier; para maturação, aonde a precocidade è geralmente desejada, destacou-se a linhạ gem da cultivar Paraná; para produção de grãos, os melhores de sempenhos foram obtidos com as linhagens das cultivares $B R-5$ e Bossier.

O aproveitamento do vigor de híbrido, em plantas de auto-fertilização, é geralmente tido como de difícil utiliza ção. Este fato é realçado na cultura da soja (BRIM, 1973). No entanto, a obtenção de combinações heteróticas, favorāveis em cruzamentos de soja, constitui-se como estímulo a estudos que permitam viabilizar a utilização funcional do vigor dehíbrido. 
A avaliação dos efeitos da heterose para o ca räter tempo de floração, revęlou a tendência dos Fi's flo rescerem precocemente em relação às médias das respectivas $1 \underline{i}$ nhagens parentais. Tal assertiva é confirmada pelo valor da heterose média negativa obtida.

Ocasionalmente, sob reduções expressivas do nü mero de dias para início da floração, podem ocorrer decréscimos indiretos no rendimento de grãos, através da diminuição do perío do vegetativo da planta. Os resultados obtidos neste estudo, no entanto, evidenciam que, para produção de hỉbridos comerciais, a redu ção do número de dias para a floração não teria maiores consequên cias. Este aspecto pode ser secundado por informações de di versos autores (WEISS et alii, 1947; BRIM e COCKERMAM, 1961 ; WEBER et alii, 1970) que relatam a ocorrência de heterose no sentido do aumento do porte das plantas em soja.

Para o carāter maturação, a anālise das médias dos $F_{1}$ 's, em relação à média dos parentais, indicou ocorrer, em média, um relativo aumento do número de dias, como evidenciado pela heterose média positiva. Porém, na maioria dos $F_{1}$ 's, a mạ turação foi intermediária à maturação dos respectivos parentais. Tais resultados são consistentes aos obtidos por WEBER et ali (1970), MILLER (1976) e WILCOX e SIMPSON (1977).

A produção de grãos, através da utilização de sẹ mentes híbridas, somente é viável nos casos onde a média do hí brido superar a média do parental superior. Em outras pala vras, a presença da heterose deve ser significativa nos cruza 
mentos. A necessidade de acentuadas divergências genēticas, en tre os parentais utilizados para formação de hỉbridos, é enfati zada por melhoristas de milho (GRIFFING e LINDSTROM, 1954 ; PaA TERNIANI e LONNQUIST, 1963) para aumentos na produção de grãos. Em soja, PASCHAL e WILCOX (19.75), estudaram a heterose resultan te de cruzamentos de 12 parentais, presumíveis de serem geneti camente diversos; a heterose média obtida, em relação ao paren tal superior, foi de $8 \%$, considerada pouco expressiva, pelos autores.

Para a produção de grãos, no presente estudo, as heteroses foram acéntuadamente baixas, embora positivas, como in dicada pela heterose média. Em relação, respectivamente à mẹ dia dos parentais e parental superior, foram obtidas médias de $10,30 \%$ e $0,49 \%$. O valor desta ūltima é muito inferior a $19,6 \%$, obtida por VEATCH (1930), $14,5 \%$ por WEISS et ali $i$ (1947), $13,8 \%$ por KALTON (1948), 20,2\% por BRIM e COCKERHAM (1961) e 8,0\% por PASCHAL e WILCOX (1975)。

As prováveis causas da presença de médias pouco expressivas de heteroses, podem ser o resultado da utilização de linhagens de cultivares altamente melhoradas ou "elites" e da inclusão de linhagens que, quando em cruzamentos, proporcionem valores negativos de heterose, como os apresentados pela linha gem da cultivar Bossier. Heteroses negativas em soja não fo ram relatadas nas literaturas consultadas.

Como possíveis explicações para o comportamento heterótico negativo da 1 inhagem da cultivar Bossier, para prodụ 
ção de grãos, são aventadas duas hipóteses: 1- Extrema diver gêcicia genética da linhagem em relação a algumas linhagens do comjunto. MOLL et alii (1965), indicam ser esta uma das causas da presença de heterose negativa em cruzamentos de milho. PAS CHAL e WILCOX (1975), obtiveram heteroses médias menores para cruzamentos de linhagens de soja, presumivelmente divergentes em relação às heteroses médias de linhagens adaptadas localmente e de mesma origem. 2- Presença de fatores epistáticos do tipo aditivo $x$ aditivo. Segundo EBERHART e GARDNER (1966), a presen ça de tal tipo de efeito, ocasiona tendências negativas de he terose.

Por outro lado, expressivas combinações heteró ticas foram obtidas para produção de grãos, em relação a média dos parentais. Neste particular, ressalta-se o Fi, resultante das linhagens Paraná e IAS-4 com 34,01\%. Entretanto, não foi obtida nenhuma média de $F_{1}$ superior à média per se da linhagem da cultivar Bossier. PASCHAL e WILCOX (1975), obtiveram apenas dois $F_{1}$ 's de médias superiores ao parental superior em soja.

As correlações significativas entre as médias dos parentais e respectivos $F_{I}$ 's, foram relativamente altas pạ ra os caracteres número de dias, para floração e maturação. Tais resultados eram previsíveis, devido a que estes caracteres, embo ra de herança quantitativa, de acordo com a literatura, apre sentam alta herdabilidade. Além disso, o controle de tais cạ racteres envolvem alguns genes comuns.

Para a produção de grãos, a ausência de correla 
ção entre as médias das linhagens parentais, e respectivos Fı's, indica haver, outras ações gênicas além das aditivas envolvi das na transmissão deste carāter. Esta evidência é corrobora da pela significância, obtida para os efeitos específicos de he terose ou capacidade específica de combinação, além dos valores relativamente altos das heteroses. Deste modo, as ações gên cas não aditivas ficam evidenciadas quando se refere ao cọntro le do carāter produção.

o valor, relativamente alto da covariância nega tiva, entre os efeitos de linhagens e efeitos de heterose das $1 \underline{i}$ nhagens, para a produção de grãos, mostra uma tendência de valo res menos expressivos de heterose, em cruzamentos envolvendo as linhagens mais produtivas e vice-versa. Tendência semelhan te, foi constatada para floração, enquanto que para a maturação, observou-se tendência inversa a dos outros dois caracteres.

\subsection{Anālise dos cruzamentos dialélicos}

\subsubsection{Generalidades}

Cruzamentos em dialélicos, envolvendo linhagens endógamas, são realizados a quatro décadas (SPRAGUE e e TATUM, 1942). Desde então, inúmeros processos estatístico-genéticos, foram propostos para añ̄ise das tabelas dialélicas.

Atualmente, os procedimentos deste tipo de anạ 1ise, são centrados em três modelos bäsicos:o de HAYMAN (1954 a e b) complementado pelo mesmo autor em anos subsequentes e por 
MATHER e JINKS (1971), sendo basicamente proposto para um mode lo de gene dialélico; o de GRIFFING (1956), um modelo mais am plo; e o de GARDNER e EBERHART (1966), proposto inicialmente pa ra variedades em equilíbrio de frequências gênicas.

Extensiva 1iteratura（NASSAR，1965; FEYT，1966; BAKER, 1978), é encontrada a respeito de dialélicos, principal mente, envolvendo aspectos críticos aos diversos métodos. ARUNACHALAM (1976), revisou os estudos realizados com cruzamentos dialélicos, envolvendo os métodos gräficos (HAYMAN, 1954) e os métodos de anālises combinatōrias (GRIFFING, 1956). De modo geral, o referido autor conclui pela prevalência dos métodos de anālises combinatórias, principalmente quando o objetivo é o de fornecer subsídios aos programas de melhoramento.

SOKOL (1976), citado por BAKER (1978), estudou estatisticamente as interrelações entre os métodos dois e quatro de Griffing, as anālises II e III de Gardner e Eberhart e a de Hayman. Concluiu o referido autor, que informações similares são obtidas dos cinco métodos de anālises, e que estas podem ser comple tamente sumarizadas nos cinco tipos de estimativas usadas na anālise III proposta por Gardner e Eberhart.

No presente estudo, em face das evidências favo ráveis aos métodos de anālise combinatória (ARUNACHALAM, 1976 ; BAKER, 1978), foram utilizados os métodos de GRIFFING (1956), para verificação da significância das variâncias de capacidade geral de combinação (c.g.c.) e variâncias dos efeitos de c.g.c. e capacidade específica de combinação (c.e.c.), associadas a ca 
da linhagem parental. 0 método proposto por GARDNER e EBERHART (1966), foi utilizado para estimação dos efeitos de c.g.c. ( $\left.\hat{g}_{i}{ }^{\prime} s\right)$, c.e.c. ( $\left.\hat{s}_{i j}{ }^{\prime} s\right)$, parâmetros relacionados a heterose presente nos cruzamentos e anālise da variância, para verificação da significância dos efeitos de 1 inhagens e de heteroses.

As significâncias dos quadrados mẻdios, obtidos com o modelo de anālise de GARDNER e EBERHART (1966), indicaram a existência de diferenças reais, entre as médias das 1 inhagens, para os três caracteres em estudo e a presença de valores dife rentes de heterose. Possivelmente a variação neste efeito ē devido a efeitos heteróticos diferenciados promovidos por algu mas 1 inhagens.

A decomposição dos efeitos de heterose para os três caracteres em estudo, em efeitos devido a heterose média, heterose de 1 inhagens e heterose especifica dos cruzamentos, revelou a existência de diferenças reais entre as médias dos cruzamentos. Tal fato indica que as médias obtidas, experimen talmente, podem ser representadas segundo o modelo completo de médias apresentado por GARDNER e EBERHART (1966).

A presença de significância para os efeitos de c.e.c. para os três caracteres das linhagens estudadas, contras ta amplamente com os resultados obtidos em milho. HALLAUER e MIRANDA FILHO (1981), apontam que em 15 estudos de dialẻlicos com variedades, apenas em quatro foram obtidos efeitos signifi cativos de c.e.c.. Porēm, em estudos de dialêlicos em soja, diversos autores obtiveram significâncias para os efeitos de 
c.e.c.: LEFFEL e WEISS (1958) para os caracteres floração, ma turação, altura de plantas e tamanho de sementes; WEBER et ali $i$ (1970) para rendimento de grãos e altura de plantas; PASCHAL e WILCoX (1975) para maturação, altura de plantas e tamanho de sementes; SRIVASTAVA et alii (1976) para floração e maturação; TOLEDO e KIIHL (1981) para floração e número de folhas trifo lioladas. Por outro lado, para a produção de grãos, não foi de tectada significância para c.e.c. por LEFFEL e WEISS (1958) e PASCHAL e WILCOX (1975). Do mesmo modo, SRIVASTAVA et ali (1976), não obtiveramsignificância para os efeitos de c.e.c. para floração. Conclui-se que em cruzamentos, envolvendo linhagens de soja, a significância da c.e.c. pode ser verificada com certa frequência, principalmente em função de combinaçôes epistáticas. Tal fato, pode ser devido à prōpria natureza homozigótica das linhagens envolvidas (HALLAUER e MIRANDA FILHO, 1981) ou à con dição de linhagens altamente desenvolvidas ou "elites"(IONNQUIST, 1963 ).

As proporções das variâncias de c.g.c. em rela ção as variâncias de c.e.c., são indicadoras da predominância de ações gênicas, segundo ARUNACHALAM (1976). As relações obtị das neste estudo, $19,62,19,72$ e 1,90 respectivamente para flo ração, maturação e produção de grãos, indicaram o predomínio de ações gênicas aditivas para os três caracteres em estudo, embora para a produção, a relação observada tenha sido acentua damente menor do que para os outros caracteres. Para produção de grãos de soja, uma relação de semelhante magnitude $(1,63)$ 
foi relatada por WEBER et alii (1970).

MATZINGER e KEMPTHORNE (1956) indicam que as ${ }_{\text {ge }}$ timativas da variância de c.g.c. incluem variâncias genéticas aditivas e epistáticas.GRIFFING (1956), também aponta que na presença de variâncias significativas de c.e.c., as variâncias de c.g.c. refletem não somente as variâncias aditivas, mas tam ţém variâncias devido a efeitos não aditivos. Daí se concluir no presente trabalho que os caracteres em estudo apresentam uma base genética cujo controle envolve ações gênicas não somente do tipo aditivo mas também os não aditivos como dominância e possivelmente epistase. A presença de heterose significativa para os três caracteres em estudo, embora em níveis diferentes de expressão, também corrobora esta conclusão. Autores como HANSON et alii (1967) e SRIVASTAVA et alii (1967), obtiveram con clusões semelhantes em estudos da produção de grãos em soja.

As estimativas dos componentes da variância não foram obtidas neste estudo. Segundo BAKER (1978), variâncias somente devem ser estimadas a partir de cruzamentos dialélicos quando na ausência de epistasia. Além disto, a estimação de variâncias para um conjunto fixo de genótipos, como o utilizado neste estudo, segundo EBERHART e GARDNER (1966), HALLAUER e MI RANDA FILHO (1981) não se constitui num procedimento adequado sendo que, o interesse principal da anālise é a estimação, dos efeitos de capacidade geral e específica de combinação.

Das anālises da variância, verificou-se que as somas de quadrados de heteroses para os caracteres, floração e 
maturação, representaram em torno de $25 \%$ da soma de quadrado to tal, enquanto para produção de grãos, tal proporção foi acima de $60 \%$. Tais aspectos, reforçam observações anteriores da pre sença de outras ações gênicas envolvidas no controle da herança dos caracteres estudados, alêm de salientar que os efeitos heteröticos são mais expressivos para a produção, do que para os outros caracteres.

6.2.2. Estimativas dos efeitos de c.e.c.e c.g.c.

Estimativas dos caracteres quando obtidas de crü zamentos dialélicos e analisados segundo um modelo fixo, permi tem a avaliação do desempenhodas linhagens segundo dois efeitos: o de capacidade geral de combinação $\left(\hat{g}_{i}\right)$ chamado também de efei to principal e o efeito de capacidade específica de combinação $\left(\widehat{s}_{i j}\right)$ chamado tambêm de interação.

Em espēcies de auto-fertilização como a soja, os efeitos de c.e.c., devido a efeitos de dominância presente nos cruzamentos, são dissipados com as auto-fecundações. Entre tanto, o efeito de interação pode ser aproveitado sob dois as pectos: 1. para fins de produção de sementes híbridas; 2 , para efeitos de seleção de linhagens homozigóticas superiores. 0 primeiro aspecto não apresenta a necessäria funcionalidade em soja, devido às dificuldades na transferência de pôlen e o se gundo citado, aumenta as chances de obtenção de genôtipos homo zigotos com alelos favorāveis para o carāter. Neste estudo, pạ ra produção de grãos, alta c.e.c. foi obtida no cruzamento das 
linhagens Bragg e $B R-1 \quad\left(\hat{s}_{6} 7=5,75 \mathrm{~g} / \mathrm{planta}\right)$.

Os efeitos de c.g.c. são considerados como ind $\underline{i}$ cadores das potencialidades dos genótipos quando em cruzamen tos. Para tempo de floração e maturação, estes efeitos não fo ram de magnitude elevada para as direções geralmente desejadas no melhoramento da soja, ou seja o retardamento do início da floração e a precocidade da maturação. Estimativas favoráveis para os dois caracteres foram obtidos na linhagem da cultivar Parană, embora ocorra relativa redução no número de dias para floração. 0 melhor desempenho, para ambos os caracteres foi obtido com a linhagem da cultivar $B R-5$.

Para produção de grãos nas linhagens estudadas, os efeitos mais significativos de c.g.c. foram obtidos respec tivamente para as linhagens das cultivares Paraná e $B R-5$. Tal fato indica, haver perspectivas favoráveis para programas de seleção recorrente.

A equação $g_{i}=\frac{1}{2} \ell_{i}+h_{i}$, apresentada por GARDNER e EBERHART (1966) a partir dos parâmetros, efeito de linhagem $\left(\ell_{i}\right)$ e efeito da heterose da linhagem $\left(h_{i}\right)$ obtidos quando da estimação das médias dos cruzamentos, revelam a natureza do e feito de c.g.c. ou $g_{i}$. A separação dos componentes dos efei tos de c.g.c. em percentagem, indicou que os fatores heterótị cos das linhagens, contribuem na composição daqueles efeitos em algumas linhagens, para um determinado caráter.

Para floração, os efeitos de c.g.c. no sentido 
da diminuição do nümero de dias, nas linhagens das cultivares Parană, IAS-4, Bragg e Bossier são totalmente devido ao respectivo efeito das próprias linhagens. O mesmo ocorre nas 1inhagens das cultivares Davis, $B R-1$ e $B R-5$ que apresentam efe $\underline{\mathbf{i}}$ tos de c.g.c. no sentido do aumento do número de dias para flo ração.

Para o caráter maturação, os componentes dos efei tos de c.g.c. apresentaram-se com participações relativamente distribuídas nas linhagens. Apenas nas linhagens das culti vares IAS-4 e Bragg, os efeitos de c.g.c. foram totalmente de vidos aos efeitos das próprias linhagens.

Para o caráter produção de grãos, o efeito positivo de c.g.c. da linhagem da cultivar Paranā é devido ao efeito de heterose de linhagem, em contraste ao efeito de c.g.c. da linhagem da cultivar $B R-5$ que é devido principalmente(69,8\%) ao efeito de linhagem.

A linhagem da cultivar Bossier apresentou o me 1hor desempenho per se para produção de grãos nas condições deste estudo. Porém, em cruzamentos o efeito dec.g.c. desta linhagem é altamente negativo. A verificação da natureza deste efeito revelou ser o mesmo devido ao efeito da heterose de linhagem. Este efeito heterótico ao lado da presença de epistasia do tipo aditiva x aditiva, como sugerido por MARTIJ (1981), pode ser aventado como provável causa do negativo desempenho combinatório desta linhagem.

0 efeito heterótico de linhagem $\left(h_{i}\right)$ segundo 
VENCOVSKY (1970) pode ser considerado como indicador do grau de divergência genética de uma variedade em relação às demais do conjunto dialélico, para um caráter qualquer.

Neste caso, segundo o mesmo autor, geralmente a variedade que apresentar o valor mais acentuadamente negativo de $h_{i}$ (para caracteres de heterose média positiva) será consi derada como de menor dêlvergência genética em relação ao cognjun to. No presente estudo, para nümero de dias para início da floração, caráter de heterose média negativa, a linhagem da cultivar Bossier foi a mais divergente; para maturação, caráter de heterose positiva, a maior divergência foi evidenciada pela linhagem da cultivar $B R-1$; para produção de grãos, caráter de heterose média positiva, a mais divergente do conjunto é a $1 \underline{i}$ nhagem da cultivar IAS-4. Com base neste princípio, o valor mais fortemente negativo de heterose da linhagem da cultivar Bossier, seria interpretado como indicador de ausência de di versidade genética em relação as demais linhagens do conjunto. Porém outras causas podem estar envolvidas como discutido ante riormente.

Alternativamente, uma comparação entre as linhạ gens do conjunto quanto ao grau de diversidade genética, pode ser feita diretamente pela heterose média de cada linhagem quan do em cruzamentos com as demais (Tabela 10). Tal estimativa $\left(\overline{\bar{h}}_{i}\right)$ tem uma relação direta com a estimativa de $\widehat{h}_{i}$ ( ítem 4.6 ) e pode ser expressa na unidade do caráter ou em percentagem da média dos parentais. Nesta comparação, destaca-se a linhagem 
da cultivar IAS-4 na qual se observou uma heterose média de $24,54 \%$, em ŗelação a média dos parentais quando em cruzamentos com as demais linhagens do conjunto para o caráter produção de grãos.

As estimativas das variâncias dos efeitos de c.g.c. e c.e.c., associadas as linhagens segundo GRIFFING (1956) são indicadoras do comportamento relativo das linhagens quando em cruzamentos dialélicos. Magnitudes relativamente pequenas das variâncias dos efeitos de c.e.c. associada a uma linhagem, re velam maior uniformidade na expressão da c.e.c. quando em cru zamentos com as demais. As magnitudes da variância da c.g.c. associadas as linhagens, indicam a relativa contribuição da $1 \underline{i}$ nhagem para a variância total do efeito de capacidade geral de combinação.

A anālise do comportamento das linhagens sob es te ângulo (GRIFFING, 1956) permitiu concluir da superioridade da linhagem da cultivar $B R-5$ sobre $B R-1$, para o caráter flora ção; para precocidade na maturação, a linhagem da cultivar Pạ rană, foi superior a da linhagem da cultivar $B R-5$. Para o cará ter produção de grãos, a linhagem da cultivar $B R-5$, devido às variâncias negligíveis do efeito médio de c.e.c., é superior as demais linhagens. Devido a este aspecto, a linhagem da culti var $B R-5$ evidencia aspectos superiores para sua inclusão em programas de seleção recorrente, para aumentos na produção de grãos:

A anālise do material em estudo, através de crü 
zamentos dialélicos foi feita inicialmente, com base na hetero se observada de cada cruzamento e na ḩeterose média (ítem 6.1). Em sequência foram analisados os efeitos de capacidade especí fica de combinação $\left(\hat{s}_{i j}\right)$, seguindo-se a anālise dos efeitos de capacidade geral de combinação $\left(\hat{g}_{i}\right)$ e dos seus componentes $\hat{l}_{i}$ (efeito de linhagem) e $\widehat{h}_{i}$ (efeito de heterose de 1 inhagem); re lacionados com este último, também foi analisada a heterose mê dia da linhagem $\left(\bar{h}_{i}\right)$. A importância de cada um dos efeitos co mo fonte de variação, foi averiguada através da anālise da variância correspondente. Como informação complementar foram analisadas as variâncias de c.g.c. e c.e.c. associadas a cada 1 inhagem. 
7. CONCLUSÕES

Como resultado do estudo realizado, são apresen tadas as seguintes conclusões:

a. A análise do comportamento das linhagens como tais e a hete rose média observada nos cruzamentos, levam a concluir que as cultivares escolhidas para o presente estudo, representam um conjunto geneticamente promissor para programas de melhora mento.

b. Embora de magnitude relativamente alta, a heterose da prod $\underline{u}$ dução de grãos, em relação a média dos parentais, contrastou com a magnitude da heterose em relação ao parental superior. Tal aspecto, evidenciou o alto desempenho de algumas linha gens per se.

c. As linhagens das cultivares $B R-5$ e Parană, as quais apresen taram os maiores valores dos efeitos $\hat{\mathrm{g}}_{i}$, representam mate riais promissores quando o objetivo é a identificação de $1 \underline{i}$ 
nhagens com alta capacidade geral de combinação.

d. As linhagens das cultivares $B R-5$ e Bossier que apresentaram os maiores valores de $\widehat{l}_{i}$, representam um alto valor intrínse co no conjunto de linhagens estudadas. Além disto, eventua 1 mente, seriam as mais indicadas para utilização em programas amplos de melhoramento. B

e. As linhagens das cultivares IAS-4 e Paraná, que apresentạ ram os maiores valores de $\widehat{h}_{i}$, representam um potencial quan do em cruzamentos com as demais linhagens do conjunto fixo estudado.

f. A avaliação das linhagens atravês dos componentes da capaci dade geral de combinação, quais sejam $\widehat{h}_{i}$ e $\hat{\ell}_{i}$, se mostram adequados por ter sido verificado que são variäveis as con tribuições relativas destes componentes. Por esta razão, as interpretações podem diferir acentuadamente daquelas obtị das atravês de anâlise direta do efeito de capacidade geral de combinação $\left(\hat{g}_{i}\right)$. Daí, a a dequação do modelo de Gardner e Eberhart às anālises de cruzamento de linhagens homozigótị cas.

g. A significância estatística detectada para todas as fontes de variação na anālise da variância, permite concluir que as médias das tabelas dialēlicas podem ser explicadas pelo modelo completo utilizado.

h. Os resultados de alguns cruzamentos específicos, indicaram que em soja,é possível a ocorrência de heteroses negativas 
para produção, embora não comumente relatadas na literatura. i. Os caracteres tempo, para inỉcio da floração e maturação, não foram decisivamente importantes para diferenciação das $1 \underline{i}$ nhagens das cultivares, quanto à aspectos de inclusão das mes mas em programas de melhoramento. Para tais caracteres, as heteroses analisadas sob os diversos componentes, evidencia ram pequena alteração no sentido do melhoramento geralmente pretendido. 
ARUNACHALAM, V., 1976. Evaluation of diallel crosses by graphycal and combining ability methods. Indian J. Genet. Plant Breed., Delhi, 36: 358-365.

BAKER, R.J., 1978. Issues in diallel, analysis. Crop Sci., Ma dison, 18: 533-536.

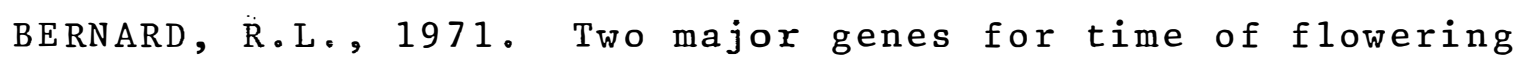
and maturity in soybeans. Crop Sci., Madison, 11: 242-244.

BERNARD, R.L. e E.R. JAYCOX, 1969. A gene for increased natural crossing in soybeans. Agron. Abstr., Am. Soc. Agron., Madison, 1969, p.3. 
BHATADE, S.S., C.B. SINGH e A.S. TIWARI, 1977. Diallel analysis of yield and its components in soybean. Pl. Breed Abstr., $48(5): 4943$. (Abstr.).

BONATO, E.R., A. DALL'AGNNOL, J.A.R.O. VELLOSO e F.J. VERNETTI, 1978. Soja: cultivar "BR-1". In: Anais. I Seminärio Nacional de Pesq. de Soja, CNPSo/EMBRAPA. Londrina, 1: 397-402.

BONATO, A.A. RAUPP e C.Q. POTOLOWSKY, 19.73. Soja - cultivar"IAS-4". Bol. Inst. Pesq. Agrop. Sul. Pelotas, 89.

BRIM, C.A., 1973. Quantitative genetics and breeding. In:

CALDWELL, B.E. (Ed.). Soybeans: Improvement, production and uses. Madison, Am. Soc, of Agron., p. 155-186.

BRIM, C.A. e C.C. COCKERHAM, 1961. The inheritance of quantitative character in soybean. Crop Sci, Madison, 1 : $187-190$

BRIM, C.A. e C.W. STUBER, 1973. Aplication on genetic male sterility to recurrent selection schemes in soybeans. Crop Sci. Madison, 13: 241-249.

BRIM, C.A. e J.W. BURTON, 1979. Recurrent selection in soybeans. II. Selection for increased percent protein in seeds. Crop Sci. Madison, 19: 494-498.

BRIM, C.A. e M.F. YOUNG, 19.71. Inheritance of a male sterile character in soybeans. Crop Sci. Madison, 11: 564-566. 
BRIM, C.A., R.L. ATHOW e J.P. ROSS, 1964. Effect of tobacco ring spot virus on natural hybridization in soybean. Agron. Abstr., Am. Soc. Agron., Madison, 1964. p.62.

BURTON, J.W. e C.A. BRIM, 1981. Recurrent selection in soybeans. III. Selection for increased percent oil in seeds. Crop Sci. Madison, 21: $31-3$.

BUZZEL, R.I., 1971. Inheritance of a soybean flowering response to fluorescent-daylength conditions. Canad. $J$. Genet. Cytol., ottawa, 13: 703-707.

COMPTON, W.A., 1268. Recurrent selection in self-pollinated crops without extensive crossing. Crop Sci., Madison, 8 : 773.

DALL'AGNOL, A., E.R. BONATO, F.J.VERNETTI, J.A.R.O. VELLOSO, B.E.V. PACOVA, A. CARNIELLI, J.V.G. FONTOURA, A.N. MESQUITA e O.R. SONEGO, 19.81. Cultivar de soja"BR-5".. In: Resumos . II Seminärio Nacional de Pesq. de Soja, Brasîlia, DF. p.135.

EBERHART, S.A. e C.0. GARDNER; 1966. A general model for genetic effects. Biometrics. Tallahasee, 22: 439-452.

FEHR, W.R., 1978. Breeding. In: NORMAN, A.G. (Ed.). Soybean physiology, agronomy and utilization. New York, Academic Press, p. 119-155. 
FEHR, W.R., 1980. Artificial hybridization and selfpollination. In: FEHR, W.R. e H.H. HADLEY (Ed.). Hybridization of crop plants. Madison, Am. Soc. Agron.Crop Sci. Soc. Am, p.105-131.

FEHR, W.R. e L.B. ORTIZ, 1975. Recurrent selection for yield in soybeans. J. Agric. Univ. Puerto Rico, 59: 222-232.

FEYT, H. 1976. Etude critique de $1^{\prime}$ analyse des croisements dialleles an moyen de la simulation. Ann. Amelior. Plantes, 26: $173-123$.

GARDNER, C.0. e S.A. EBERHART, 1966. Analys is and interpretation of the variety cross diallel and related populations. Biometrics, Tallahasee, 22: 439-452.

GILIOLI, J.L., E. PALUDZYSZYN FILHO, R.A.S . KIIHL, D.L.P. GAZZIERO e E. BORDIN, 1978. Escolha e recomendação de cultivạ res de soja. In: Manual Agropecuärio para o Paraná. Relató rio, Fund. Inst. Agron, do Paranä, Londrina, p. 357-369.

GOMES, F.P., 1977. Curso de Estatistica Experimental. 7a edição. São Paúlo, Livr. Nobel. $430 \mathrm{p}$.

GRIFFING, B. e E.W. LINDSTROM, 1954. A study of combining abilities of corn inbreds having varying proportions of cornbelt and non-cornbelt germ-plasm. Agron. J., Madison, 46: $545-552$. 
GRIFFING, B., 1956a. A generalized treatment of the use of diallel crosses in quantitative inheritance. Heredity, Edinburg, 10: $31-50$.

GRIFFING, B., 1256b. Concept of general and specific combining ability in relation to diallel crossing systems. Aust. J. Biol. Sci., 9: 463-493.

HALLAUER, A.R. e J.B. MIRANDA FILHO, 1981. Quantitative Genetics in Maize Breeding. Ames, Iowa State University Press, $468 \mathrm{p}$.

HANSON, W.D., A.M. PROBST e B.E. CALDWELL, 1967. Evaluation of a population of soybean genotypes with implications for improving self-pollinated crops. Crop Sci. Madison, $\underline{7}$ : 99- 103 .

HAYMAN, B.I., 19.54a. The analysis of variance of diallel tables. Biometrics, Tallahasee, 10: 235-244.

HAYMAN, B.I., 1954b. The theory and analysis of diallel crosses. Genetics, Tallahasee, 39: 789-809.

HYMOWITZ, T., C.A. NEWELL e S.G. CARMER, 1977. Pedigrees of soybean cultivars released in the United States and Canada. Intsoy Séries, 13. University of Illinois, I11inois, 22p. JENSEN, N.F., 1970. A diallel selective mating system for cereal breeding. Crop Sci. Madison, 10: 629-636. 
JOHNSON, M.W. e R.L. BERNARD, 19.63. Soybean genetics and breeding. In: NORMAN, A.G. (Ed.) The Soybean. New York, Academic Press, p. 1-73.

JOHNSON, G.R., 1973. Diallel analysis of leaf heterosis and relationships to yield in maize. Crop Sci. Madison, 13: $178-180$

JYANG, K.Y., 1975. Genetics analysis of flowering date of soybean by means of a diallel cross. PZ. Breed. Abstr., $47(2): 1812$. (Abstr.).

JYANG, K.Y. e J.C. BAK, 1977. Genetical analysis of quantitative characteres in different generations of a diallel cross of soybean. PZ. Breed. Abstr., 49 (4): 3244. (Abstr.).

KALTON, R.R., 19.48. Breeding behaviour in successive generation following hybridization in soybeans. Iowa Agric. Exp. Stn. Res. Buzl., 358 .

KASTER, M., E.F. QUEIROZ, F.J • VERNETTI e F. TERASAWA, 1978 . Soja: cultivar "Paranâ" - descrição e comportamento. In: Anais. I Seminārio Nacional de Pesquisa de Soja, CNPSo/EMBRAPA . Londrina, $\underline{1}: 389-322$.

KAW, R.N. e P.M. MENON, 1978. Line $x$ tester analysis of combining ability in soybean. Pl. Breed. Abstr. 49(6): 5339. (Abstr.). 
KAW, R.N. e P.M. MENON, 1281. Combining ability in soybean. Pl. Breed. Abstr. 51(10):9318. (Abstr.).

KENWORTHY, W.J. e C.A. BRIM, 1979. Recurrent selection in soybeans. I. seed yield. Crop Sci. Madison, 19:315-318.

KHADR, F.H. e K.J. FREY, 1965. Effectiveness of recurrent selection in oat breeding. Crop Sci. Madison, 5: 349-354.

KIIHL, R.A.S., 1976. Inheritance studies of two characteristics in soybeans: I - Resistance to soybean mosaic virus, II - Late flowering under short day conditions. Mississippi, Miss. State University, 56p. (Ph.D. Thesis).

LEFFEL, R.C. e M.G. WEISS, 1958. Analysis of diallel crosses among ten varieties of soybeans. Agron. J. Madison, 50: $528-534$.

LONNQUIST, J.H., 1963. Gene action and corn yields. In:

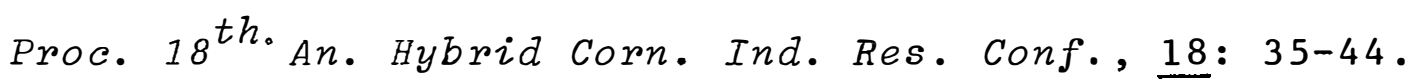

MARTIN, S.K. ST., 1981. Epistasis and soybean breeding. Soybean Genet. News 7 . Ames, 8: 104-106.

MATHER, K. e J.L. JINKS, 1971. Biometrical Genetics. Londres, Chapman e Ha11, $382 \mathrm{p}$.

MATZINGER, D.F. e O. KEMPTHORNE, 1956. The modified diallel table with partial inbreeding and interactions with environment. Genetics, Tallahasee, 41: 822-833. 
MILLER, T.C., 1976. Combining ability of protein and other, selected characters with the $F_{1}$ and $F_{2}$ plant generation of two-way crosses of ten soybeans 1 ines. Pl. Breed. Abstr., 49 $(12): 11418$. (AБstr.).

MIRANDA FILHO, J.B., 1974. Cruzamentos dialëlicos e síntese de compostos de milho com ênfase na produtividade e no por te da planta. Piracicaba, ESALQ/USP. 116p. (Tese de Dou torado).

MOLL, R.H., J.H. LONNQUIST, J.V. FORTUNO e E.C. JOHNSON, 1965 . The relationship of heterosis and genetic divergence in maize. Genetics, Tal1ahasee, 52: 139-144.

NASSAR, R.F., 1965. Effect of correlated gene distribution due to sampling on the diallel analysis. Genetics, Ta11ahasee, 52: 9-20.

PASCHAL II, E.H. e J.R. WILCOX, 1975. Heterosis and combining ability in exotic soybean germplasm. Crop Sci., Madison, 15: $344-349$.

PATERNIANI, E . e J.H. LONNQUIST, 1963. Heterosis in interracial crosse : of corn. Crop Sci., Madison, 3: 504-507.

SANTOS, E.0., 19.78. Germplasm evaluation and inheritance studies of stomata density and other plant characteristics in soybean. Pl. Breed. Abstr. 50(9): 8284. (Abstr.). 
SENWA, J.0., 1978. Germplasm evaluation and inheritance studies and seedling vigor under imbibitional chiling stress. PZ. Breed. Abstr. $50(6): 5889$. (Abstr.).

SOKOL, M.J., 19.76. Evaluation of diallel analysis with respect to the genetics and breeding of self-pollinated crops. Manitoba, Univ. of Manitoba, 63p. (MS

SPRAGUE, G.F. e L.A. TATUM, 1942. General versus specific combining ability single crosses of corn. J.Am. Soc. Agron., Madison, 34: $923-9.32$.

SPRAGUE, G.F., 1966. Quantitative Genetics in Plant Improvement. In: FREY, K.J. (Ed.) Plant Breeding. Ames, Iowa State University Press, p.315-354.

SPRAGUE, G.F., 1267. Plant Breeding. In: An. Rev. Genet. 1: $269-294$.

SRIVASTAVA, R.L., J.K. SAXENA, Z, AHMAD e R.S. BHATIA, 1978 . Genetics of yield and yield component traits in soybean. Indian J. Genet. PZant. Breed., Delhi, 38: 7-10.

TOLEDO, J.F.F. e KIIHL, R.A.S., 1981. Mẻtodos de anälise dialēlica do modelo genētico em controle das caracterîsticas dias para floração e nümero de folhas trifolioladas em soja. Submetido a Revista $P A B$. Brasîlia, para publicação. 
VEATCH, C., 1930. Vigor in soybeans as affected by hybridity. J.Am. Soc. Agron., Madison, 22: 289-310.

VENCOVSKY, R., 1969. Anālise de cruzamentos dialélicos entre variedades pelo método de Gardner e Eberhart. Rel. Cient. I. Gen. Piracicaba, 3: 99-111.

VENGOVSKY, R., 1970. Alguns aspectos teóricos e aplicados re lativos a cruzamentos dialēlicos de variedades. Piracicaba, ESALQ/USP., 59p. (Tese de Livre-Docência).

WEBER, C.R. e W.R. FEHR, 1967. Effect of hybridization and thermal neutron irradiation on quantitative characters of soybeans. Crop Sci., Madison, 7: 78 .

WEBER, C.R., L.T. EMPIG e J.C. THORNE, 1970. Heterotic performance and combining ability of two-way $F_{1}$ soybean hybrids. Crop Sci., Madison, 10: 159-160.

WEISS, M.G., C.R. WEBER e R.R. KALTON, 1247. Early generation testing in soybeans. J.Am. Soc. Agron, Madison, 39: $791-811$

WILCOX, J.R. e A.M. SIMPSON, Jr., 1977. Performance of reciprocal soybean hybrids. Crop Sci., Madison, 17: 351352 . 
.73.

TABELAS E FIGURAS 
Tabela 1. Valores, significâncias dos quadrados médios e coeficientes de variação obtidos nas anālises da variância para os três caraç teres em estudo: NDF: número de dias para início da floração, NDM: número de dias para maturação e PG: produção de grãos ( $g /$ planta). Blocos casualizados com seis repetições. Londrina-PR, 1980/81.

\begin{tabular}{lcccc}
\hline \multirow{2}{*}{ F.V. } & & \multicolumn{2}{c}{ Quadrados médios $\left(\times 10^{-2}\right)$} \\
\cline { 3 - 5 } & G.L. & NDF & NDM & PG \\
Blocos & 5 & $0,1733 * *$ & $2,1099 * *$ & $0,1298^{\text {ns }}$ \\
Tratamentos & 35 & $0,6779 * *$ & $3,9213 * *$ & $0,7865^{* *}$ \\
Erro experimenta1 & 174 & 0,0223 & 0,2986 & 0,1596 \\
& & & & \\
Coeficiente de variação (\%) & 4,49 & 4,41 & 15,25 \\
\end{tabular}

$+\quad$ : 173 GL para PG: produção de grãos

ns : não significativo

** : significativo ao nível de $1 \%$ de probabilidade 
Tabela 2. Médias observådas do carāter número de dias para início da flo ração (NDF) de oito linhagens e respectivos $F_{1}^{\prime}$ s em cruzamen tos dialélicos. Médias de duas plantas por vaso em seis repeti ções. $(1980 / 81)$.

\begin{tabular}{|c|c|c|c|c|c|c|c|c|}
\hline Linhagem & 1 & 2 & 3 & 4 & 5 & 6 & 7 & 8 \\
\hline 1 & 36,75 & 34,75 & 30,67 & 35,42 & 35,92 & 31,50 & 37,17 & 34,50 \\
\hline 2 & & 32,17 & 30,50 & 33,17 & 33,50 & 30,58 & 33,08 & 31,17 \\
\hline 3 & & & 26,25 & 30,83 & 32,67 & 27,58 & 31,75 & 30,67 \\
\hline 4 & & & & 37,00 & 34,92 & 31,00 & 35,92 & 32,50 \\
\hline 5 & & & & & 38,25 & 30,75 & 37,67 & 35,00 \\
\hline 6 & & & & & & 28,25 & 32,75 & 31,50 \\
\hline 7 & & & & & & & 38,50 & 32,17 \\
\hline 8 & & & & & & & & 42,42 \\
\hline
\end{tabular}

1. Pérola; 2. Paranā; 3. IAS-4; 4. Davis; 5. BR-5; 6. Bragg; 7. BR-1; 8. Bossier. 
Tabela 3. Médias observadas do carāter número de dias" para maturação (NDM) de oito linhagens e respectivos $\underline{F}_{1}$ 's em cruzamentos dia lélicos. Médias obtidas de duas plantas por vaso em seis repe tições. (1980/81).

\begin{tabular}{|c|c|c|c|c|c|c|c|c|}
\hline Li nhagem & 1 & 2 & 3 & 4 & 5 & 6 & 7 & 8 \\
\hline 1 & 119,08 & 109,67 & 127,25 & 124,42 & 112,00 & 124,00 & 132,42 & 131,74 \\
\hline 2 & & 104,17 & 118,92 & 117,08 & 110,08 & 116,50 & 130,83 & 118,58 \\
\hline 3 & & & 128,08 & 122,83 & 124,17 & 128,17 & 137,42 & 124,25 \\
\hline 4 & & & & 120,25 & 115,00 & 123,67 & 131,42 & 127,00 \\
\hline 5 & & & & & 111,92 & 123,88 & 130,50 & 127,17 \\
\hline 6 & & & & & & 129,67 & 135,33 & 131,42 \\
\hline 7 & & & & & & & 128,08 & 138,33 \\
\hline 8 & & & & & & & & 124,08 \\
\hline
\end{tabular}

1. Pérola; 2. Paranā; 3. IAS-4; 4: Davis; 5. BR-5; 6. Bragg; 7. BR-1; 8. Bossier 
Tabela 4. Médias observadas do carāter produção de grãos (PG) em gramas por planta de oito linhagens e respectivos $\mathrm{F}_{1}$ 's em cruzamentos dialélicos. Médias de duas plantas por vaso em seis repetições. $(1980 / 81)$.

\begin{tabular}{|c|c|c|c|c|c|c|c|c|}
\hline Linhagem & 1 & 2 & 3 & 4 & 5 & 6 & 7 & 8 \\
\hline 1 & 20,61 & 27,21 & 23,26 & 26,27 & 30,81 & 23,40 & 23,64 & 25,25 \\
\hline 2 & & 23,37 & 27,13 & 25,12 & 31,22 & 30,71 & 23,47 & 28,24 \\
\hline 3 & & & 17,12 & 26,99 & 30,83 & 25,20 & 20,98 & 30,52 \\
\hline 4 & & & & 24,34 & 29,67 & 21,84 & 28,17 & 23,28 \\
\hline 5 & & & & & 29,17 & 26,84 & 28,94 & 30,08 \\
\hline 6 & & & & & & 23,00 & 30,63 & 27,80 \\
\hline 7 & & & & & & & 24,98 & 21,03 \\
\hline 8 & & & & & & & & 31,40 \\
\hline
\end{tabular}

1. Pērola; 2. Paranā; 3. IAS-4; 4. Davis; 5. BR-5; 6. Bragg; 7. BR-1; 8. Bossier 
Tabela 5. Valores e significâncias dos quadrados médios obtidos nas aná lises da variāncia das tabelas dialélicas segundo o modelo de GARDN ER e EBERHART (1966) e da capacidade geral de combinação (c.g.c.) segundo o método 4, modelo I de GRIFFING (1956), para os três caracteres em estudo: N DF: número de dias para início da floração, N DM: número de dị́s para maturação e PG: prodụ ção de grãos.

\begin{tabular}{lcccc}
\hline F.V. & Q.L. & Quadrados Médios $\left(x 10^{-2}\right)$ \\
\cline { 3 - 4 } & & N DF & N DM & PG \\
Tratamentos & $(35)$ & $0,1128 * *$ & $0,6598 * *$ & $0,1322 * *$ \\
Linhagens & 7 & $0,4178 * *$ & $2,6108 * *$ & $0,2501 * *$ \\
Heteroses & $(28)$ & $0,0366 * *$ & $0,1721 * *$ & $0,1027 * *$ \\
Heterose média & 1 & $0,2788 * *$ & $0,1046 * *$ & $0,3884 * *$ \\
Heterose linhagens & 7 & $0,0782 * *$ & $0,2395 * *$ & $0,1140 * *$ \\
Heterose específica & 20 & $0,0099 * *$ & $0,1047 * *$ & $0,0844 * *$ \\
Erro médio & 174 & 0,0037 & 0,0498 & 0,0266 \\
\hline
\end{tabular}

$* *$ : significativo ao nível de $1 \%$ de probabilidade

+ : 173 GL para PG: produção de grãos 
Tabela 6. Estimativas dos parâmetros: $\widehat{h}_{i j}$-heterose do cruzamento $i j$ (aci ma da diagonal), $\widehat{s}_{i j}$ - heterose específica ou capacidade espe cífica de combinação (abaixo da diagonal), $\widehat{u}$ - média das linha gens parentais e $\hat{\bar{h}}$ - heterose média de todos os cruzamentos, para o carāter NDF: número de dias para início da floração.

\begin{tabular}{ccccccccc} 
Linhagem & 1 & 2 & 3 & 4 & 5 & 6 & 7 & 8 \\
\hline 1 & & & & & & & & \\
2 & 0,76 & & 1,29 & $-1,41$ & $-1,71$ & 0,37 & $-2,29$ & $-6,12$ \\
3 & $-1,31$ & 0,72 & & $-0,79$ & 0,42 & 0,33 & $-0,66$ & $-3,66$ \\
4 & 0,26 & 0,21 & $-0,12$ & & $-2,70$ & $-1,62$ & $-1,87$ & $-7,21$ \\
5 & $-0,34$ & $-0,57$ & 0,61 & $-0,32$ & & $-2,53$ & $-0,74$ & $-5,33$ \\
6 & $-0,64$ & 0,64 & $-0,35$ & $-0,11$ & $-1,46$ & & $-0,66$ & $-3,83$ \\
7 & 0,89 & $-1,01$ & $-0,32$ & 0,67 & 1,31 & 0,52 & & $-8,33$ \\
8 & 0,38 & $-0,75$ & 0,76 & $-0,59$ & 0,80 & 1,43 & $-2,04$ &
\end{tabular}

$$
\widehat{\mathrm{u}}=34,959( \pm 0,216) ; \quad \hat{\overline{\mathrm{h}}}=-2,117( \pm 0,248)
$$

1. Pérola; 2. Paranā; 3. IAS-4; 4. Vavis; 5. BR-5; 6. Bragg; 7. BR-1; 8. Bossier 
Tabela 7. Estimativas dos parânetros: $\widehat{h}_{i j}$-heterose do cruzamento $i j$ (aci ma da diagonal), $\hat{s}_{\underline{i j}}$ - heterose específica ou capacidade espe cífica de combinação (abaixo da diagonal), $\hat{\mathrm{u}}$ - média das 1inha gens parentais e $\widehat{\bar{h}}$ - heterose média de todos os cruzamentos, para o carāter NDM: nümero de dias para maturação.

\begin{tabular}{|c|c|c|c|c|c|c|c|c|}
\hline Linhagem & 1 & 2 & 3 & 4 & 5 & 6 & 7 & 8 \\
\hline 1 & & $-1,95$ & 3,67 & 4,75 & $-3,50$ & $-0,37$ & 8,84 & 9,59 \\
\hline 2 & $-4,40$ & & 2,79 & 4,87 & 2,03 & $-0,42$ & 14,70 & 4,45 \\
\hline 3 & 2,95 & 1,16 & & $-1,33$ & 4,17 & $-0,70$ & 9,34 & $-1,83$ \\
\hline 4 & 3,72 & 2,92 & $-1,55$ & & $-1,08$ & $-1,29$ & 7,25 & 4,83 \\
\hline 5 & $-5,55$ & $-0,97$ & 2,89 & $-2,68$ & & 3,08 & 10,50 & 9,17 \\
\hline 6 & $-0,29$ & $-1,25$ & 0,20 & $-0,70$ & 2,61 & & 6,45 & 4,54 \\
\hline 7 & $-0,75$ & 4,20 & 0,57 & $-1,83$ & 0,35 & $-1,52$ & & 12,25 \\
\hline 8 & 4,38 & $-1,66$ & $-6,21$ & 0,13 & 3,41 & 0,96 & $-1,01$ & \\
\hline & \multicolumn{4}{|c|}{$\overline{\mathrm{u}}=120,666( \pm 0,789)$} & \multicolumn{4}{|c|}{$\overline{\overline{\mathrm{h}}}=4,101( \pm 0,894)$} \\
\hline
\end{tabular}

1. Pērola; 2. Paranā; 3. IAS-4; 4. Davis; 5. BR-5; 6. Bragg; 7. BR-1; 8. Bassier 
Tabela 8. Estimativas dos parâmetros: $\hat{\mathrm{h}}_{i j}$-heterose do cruzamento $\mathrm{ij}$ (aci ma da diagonal), $\hat{s}_{i j}$ - heterose específica ou capacidade espe cĩfica de combinação (abaixo da diagonal), $\hat{u}$ - média das linhạ gens parentais e $\hat{\bar{h}}$ - heterose média de todos os cruzamentos, para o caráter PG: produção de grãos (g/planta).

\begin{tabular}{ccccccccc} 
Linhagem & 1 & 2 & 3 & 4 & 5 & 6 & 7 & 8 \\
\hline 1 & & & & & & & & \\
& & & & & & & \\
2 & & & & & & & & \\
2 & 0,65 & & 6,88 & 1,26 & 4,95 & 7,52 & $-0,70$ & 0,85 \\
3 & $-1,93$ & $-0,21$ & & 6,26 & 7,68 & 5,14 & $-0,07$ & 6,26 \\
4 & 2,00 & $-1,69$ & 1,54 & & 2,91 & $-1,83$ & 3,51 & $-4,59$ \\
5 & 1,70 & $-0,03$ & 0,94 & 0,31 & & 0,74 & 1,86 & $-0,20$ \\
6 & $-2,04$ & 3,12 & $-1,02$ & $-3,85$ & $-3,30$ & & 6,64 & 0,60 \\
7 & $-0,21$ & $-2,53$ & $-3,65$ & 4,06 & 0,40 & 5,75 & & $-7,16$ \\
8 & $-0,16$ & 0,69 & 4,33 & $-2,38$ & $-0,02$ & 1,36 & $-3,82$ &
\end{tabular}

$$
\hat{\mathrm{u}}=24,249( \pm 0,577) ; \quad \hat{\overline{\mathrm{h}}}=2,498( \pm 0,654)
$$

1. Pérola; 2. Paranā; 3. IAS-4; 4. Davis; 5. BR-5; 6. Bragg; 7. BR-1; 8. Bossier 
Tabela 9. Estimativas das heteroses da produção de grãos em porcentagem da média dos parentais (acima da diagonal) e em porcentagem do parental superior (abaixo da diagonal), observados nos $\mathrm{F}_{1}$ 's.

\begin{tabular}{crrrrrrrr} 
Linhagem & 1 & 2 & 3 & 4 & 5 & 6 & 7 & 8 \\
& \multicolumn{1}{c}{1} & & & & & & \\
1 & & 23,74 & 23,30 & 16,88 & 23,78 & 7,31 & 3,71 & $-2,90$ \\
2 & 16,43 & - & 34,01 & 5,30 & 18,84 & 32,46 & $-2,92$ & 3,12 \\
3 & 12,86 & 16,09 & - & 30,20 & 33,20 & 25,62 & $-0,33$ & 25,80 \\
4 & 9,57 & 3,20 & 10,89 & - & 10,89 & $-7,73$ & 14,23 & $-16,47$ \\
5 & 5,62 & 7,03 & 5,70 & 1,71 & - & 2,89 & 10,56 & $-0,68$ \\
6 & 1,74 & 31,41 & 9,56 & $-10,27$ & 8,02 & - & 27,68 & 2,20 \\
7 & $-5,36$ & $-6,04$ & $-16,01$ & 12,77 & $-0,79$ & 22,62 & - & $-25,40$ \\
8 & $-19,58$ & $-10,06$ & $-2,80$ & $-25,86$ & $-4,20$ & $-11,46$ & $-33,02$ & -
\end{tabular}

1. Pérola; 2. Paranā; 3. IAS-4; 4. Davis; 5. BR-5; 6. Bragg; 7. BR-1;

3. Bossier 
Tabela 10. Heterose média das linhagens parentais $\left(\hat{\bar{h}}_{\dot{i}}\right)$ resultantes dos cruzamentos em dialélico para os caracteres nümero de dias pạ ra início da floração (NDF), número de dias para maturação (NDM) e produção de grãos em gramas/planta e em porcentagem.

\begin{tabular}{|c|c|c|c|c|}
\hline \multirow{2}{*}{ Linhagem } & \multicolumn{4}{|c|}{ Heterose Média da linhagem $\left(\tilde{\bar{h}}_{i}\right)$} \\
\hline & $\mathrm{NDF}$ & NDM & $\begin{array}{c}\text { PG } \\
(\mathrm{g} / \mathrm{planta})\end{array}$ & $\begin{array}{l}\text { PG } \\
(\%)\end{array}$ \\
\hline 1 & $-1,4507$ & 3,0035 & 3,0592 & 13,69 \\
\hline 2 & $-1,3709$ & 3,7835 & 3,7045 & 16,36 \\
\hline 3 & $-0,5594$ & 2,3006 & 5,2130 & 24,54 \\
\hline 4 & $-2,4402$ & 2,5721 & 1,6660 & 7,61 \\
\hline 5 & $-2,0264$ & 3,4821 & 3,4016 & 14,21 \\
\hline 6 & $-1,2793$ & 1,6135 & 2,9073 & 12,92 \\
\hline 7 & $-2,1517$ & 9,9064 & 0,6945 & 3,93 \\
\hline 8 & $-5,6550$ & 6,1449 & $-0,7227$ & $-2,05$ \\
\hline
\end{tabular}

1. Pérola; 2. Paranā; 3. IAS-4; 4. Davis; 5. BR-5; 6. Bragg; 7. BR-1; 8. Bossier 
Tabela 11. Estimativas dos parâmetros: $\hat{\ell}_{i}$-efeito de linhagens, $\hat{\mathrm{h}}_{\mathfrak{i}}$ - efe $\underline{i}$ to de heterose das linhagens, $\hat{\mathrm{g}}_{\mathrm{i}}$ - efeito de capacidade geral de combinação (c.g.c.) e as estimativas das variāncias das capacidades geral $\left(\widehat{\sigma}^{2} \cdot \hat{g}_{i}\right)$ e específica $\left(\widehat{\sigma}^{2} \hat{s}_{i}\right)$ de combinação das linhagens para o carāter NDF: número de dias para início da floraşão.

$\begin{array}{llllll}\text { Linhagem } & \hat{\ell}_{i} & \hat{h}_{i} & \hat{g}_{i} & \hat{\sigma}^{2} \hat{g}_{i} & \hat{\sigma}^{2} \hat{s}_{i}\end{array}$

\begin{tabular}{cccccc}
\hline 1 & 1,7912 & 0,7769 & 1,6725 & 2,7428 & 0,3263 \\
2 & $-2,7887$ & 0,8700 & $-0,5243$ & 0,2205 & 0,2653 \\
3 & $-8,7087$ & 1,8168 & $-2,5375$ & 6,3845 & 0,2597 \\
4 & 2,0413 & $-0,3764$ & 0,6442 & 0,3606 & $-0,1379$ \\
5 & 3,2913 & 0,1052 & 1,7508 & 3,0109 & 0,5896 \\
6 & $-6,7087$ & 0,9769 & $-2,3774$ & 5,5976 & 0,5892 \\
7 & 3,6213 & $-0,0410$ & 1,7696 & 3,0770 & 1,1077 \\
8 & 7,4613 & $-4,1281$ & $-0,3974$ & 0,1035 & 1,1023 \\
\hline $\mathrm{s}$ & $\pm 0,571$ & $\pm 0,286$ & $\pm 0,233$ & - & - \\
\hline vâr $\left(\mathrm{g}_{j}-\hat{g}_{j}\right)$ & & 0,124 & & \\
\hline
\end{tabular}

1.Pérola; 2. Paranā; 3. IAS-4; 4. Davis; 5. BR-5; 6. Bragg; 7. BR-1; 8. Bossier $\widehat{s}$ - desvio padrão das estimativas dos efeitos de linhagens e dos efeitos de heterose das linhagens.

$\operatorname{var}\left(\hat{\mathrm{g}}_{i}-\widehat{\mathrm{g}}_{j}\right)$ - variāncia das diferenças entre as estimativas dos efeitos de capacidade geral de combinação. 
Tabela 12. Estimativas dos parâmetros: $\hat{\ell}_{i}$ - efeito de linhagens, $\hat{\mathrm{h}}_{\mathbf{i}}$ - $\mathrm{e}$ feito de heterose das 1 inhagens, $\hat{g}_{i}$ - efeito de capacidade ge ral de combinação (c.g.c.), e as estimativas das variâncias das capacidades geral $\left(\hat{\sigma}^{2} \hat{g}_{i}\right)$ e específica $\left(\hat{\sigma}^{2} \hat{s}_{i}\right)$ de combina ção das linhagens para o carāter NDM: nümero de dias para ma turação.

\begin{tabular}{|c|c|c|c|c|c|}
\hline Li nhagem & $\hat{l}_{i}$ & $\hat{\mathrm{h}}_{\mathrm{i}}$ & $\widehat{g}_{i}$ & $\hat{\sigma}^{2} \hat{\mathrm{g}}_{\mathbf{i}}$ & $\sigma^{2} \widehat{s}_{i}$ \\
\hline 1 & $-1,5862$ & $-1,2802$ & $-2,0733$ & 3,5728 & 11,2752 \\
\hline 2 & $-16,4962$ & $-0,3702$ & $-8,6183$ & 73,5493 & 4,5413 \\
\hline 3 & 7,4183 & $-2,1002$ & 1,6067 & 1,8557 & 5,8081 \\
\hline 4 & $-0,4162$ & $-1,7835$ & $-1,9916$ & 3,2407 & 1,8204 \\
\hline 5 & $-8,7462$ & $-0,7218$ & $-5,0949$ & 25,2322 & 6,8205 \\
\hline 6 & 9,0038 & $-2,9018$ & 1,6001 & 1,8345 & $-2,1104$ \\
\hline 7 & 7,4138 & 6,7731 & 10,4801 & 109,1067 & 0,0744 \\
\hline 8 & 3,4138 & 2,3848 & 4,0917 & 16,0162 & 8,2013 \\
\hline s & $\pm 2,087$ & $\pm 1,347$ & $\pm 0,852$ & - & - \\
\hline \multicolumn{3}{|c|}{$\operatorname{var}\left(\hat{g}_{i}-\hat{g}_{j}\right)$} & 1,659 & & \\
\hline
\end{tabular}

1. Pérola; 2. Paranā; 3. IAS-4; 4. Davis; 5. BR-5; 6. Bragg; 7. BR-1; 8. Bossier $\widehat{\mathbf{s}}$ - desvio padrão das estimativas dos efeitos de linhagens e dos efeitos de heterose das linhagens.

$\operatorname{var}\left(\hat{g}_{i}-\hat{g}_{j}\right)$ - variāncia das diferenças entre as estimativas dos efeitos de capacidade geral de combinação. 
Tabela 13. Estimativas dos parâmetros: $\hat{l}_{i}$ - efeito de linhagens, $\hat{\mathrm{h}}_{\mathbf{i}}$ - $\underline{\text { e }}$ feito de heterose das 1 inhagens, $\bar{g}_{i}$ - efeito" de capacidade ge ral de combinação (c.g.c.), e as estimativas das variâncias das capacidades geral $\left(\widehat{\sigma}^{2} \widehat{g}_{i}\right)$ e específica $\left(\hat{\sigma}^{2} \widehat{s}_{i}\right)$ de combinação associada as linhagens para o carāter PG: produção de grãos (g/ planta).

\begin{tabular}{|c|c|c|c|c|c|}
\hline Linhagem & $\hat{\ell}_{i}$ & $\hat{\mathrm{h}}_{\mathrm{i}}$ & $\hat{\mathrm{g}}_{i}$ & $\hat{\sigma}^{2} \widehat{g}_{i}$ & $\hat{\sigma}^{2} \hat{s}_{i}$ \\
\hline 1 & $-3,6387$ & 0,6544 & $-1,1649$ & 1,0246 & $-0,5585$ \\
\hline 2 & $-0,8787$ & 1,4177 & 0,9780 & 0,6240 & 0,2192 \\
\hline 3 & $-7,1287$ & 3,1777 & $-0,3866$ & $-0,1830$ & 3,5860 \\
\hline 4 & 0,0913 & $-0,9606$ & $-0,9149$ & 0,5046 & 4,6124 \\
\hline 5 & 4,9213 & 1,0644 & 3,5250 & 12,0935 & $-0,6164$ \\
\hline 6 & $-1,2487$ & 0,4877 & $-0,1366$ & $-0,3138$ & 9,4902 \\
\hline 7 & 0,7313 & $-2,0939$ & $-1,7282$ & 2,6543 & 10,9077 \\
\hline 8 & 7,1513 & $-3,7473$ & $-0,1716$ & $-0,3030$ & 3,7896 \\
\hline $\mathrm{s}$ & $\pm 1,526$ & $\pm 0,985$ & $\pm 0,623$ & - & - \\
\hline \multicolumn{2}{|c|}{$\hat{\operatorname{varr}}\left(\hat{\mathrm{g}}_{i}-\hat{\mathrm{g}}_{j}\right)$} & & 1,659 & & \\
\hline
\end{tabular}

1. Pérola; 2. Paranā; 3. IAS-4; 4. Davis; 5. BR-5; 6. Bragg; 7. BR-1; 8. Bossier $\widehat{s}$ - desvio padrão das estimativas dos efeitos de linhagens e dos efeitos de heterose das linhagens.

$\operatorname{var}\left(\hat{g}_{i}-\hat{g}_{j}\right)$ - variância das diferenças entre as estimativas dos efeitos de capacidade geral de combinação. 
.87.

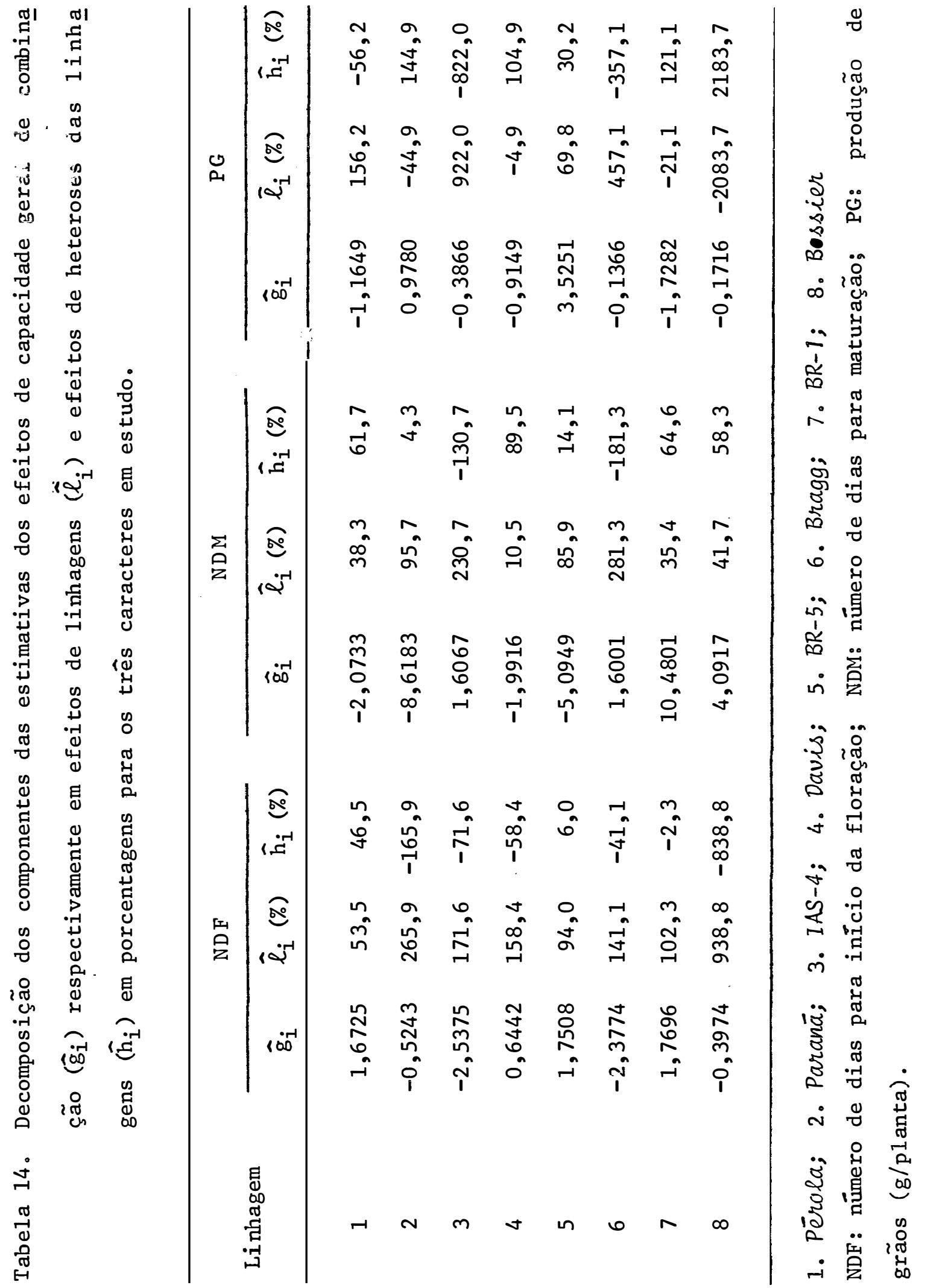


.88.

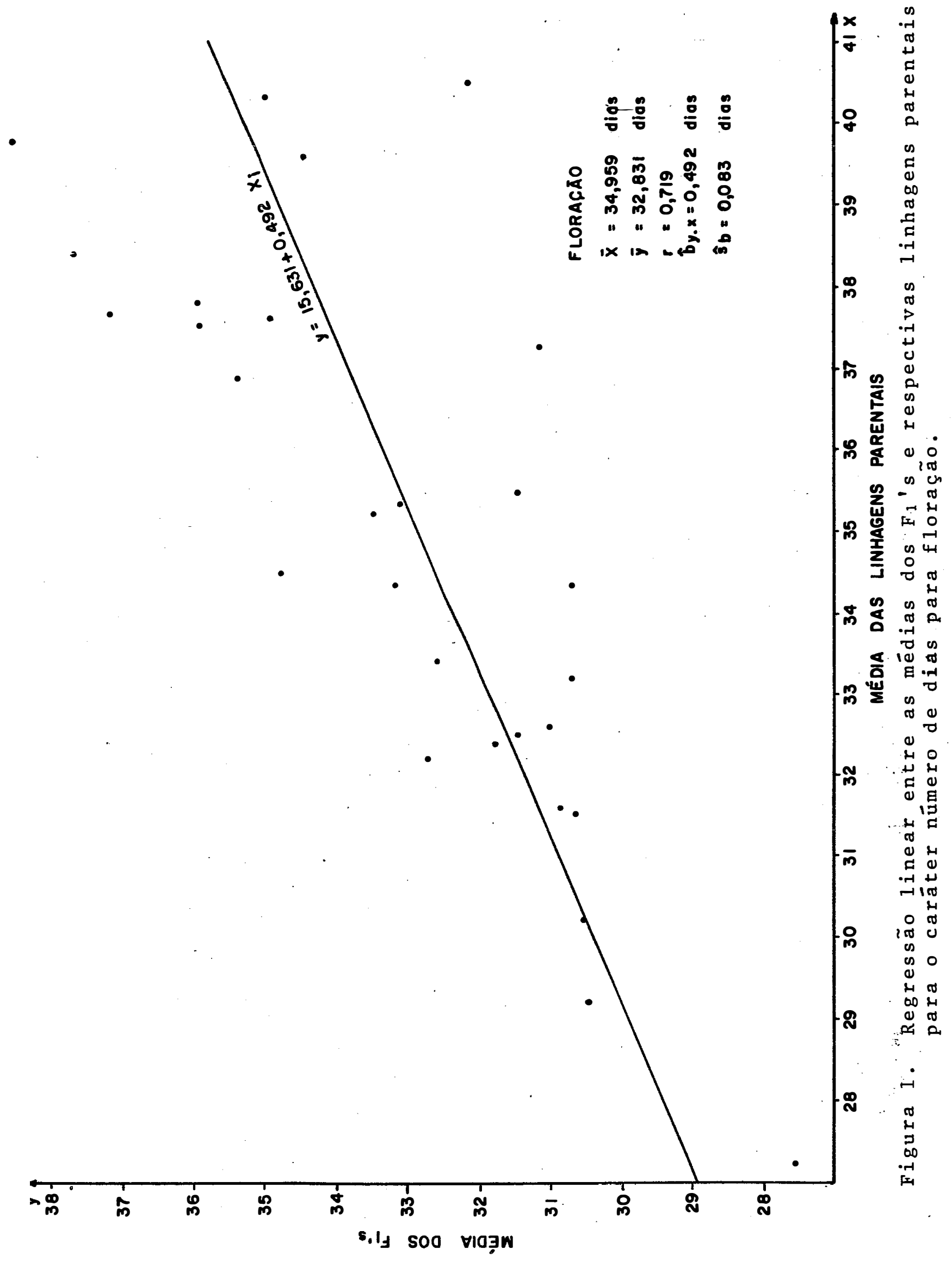




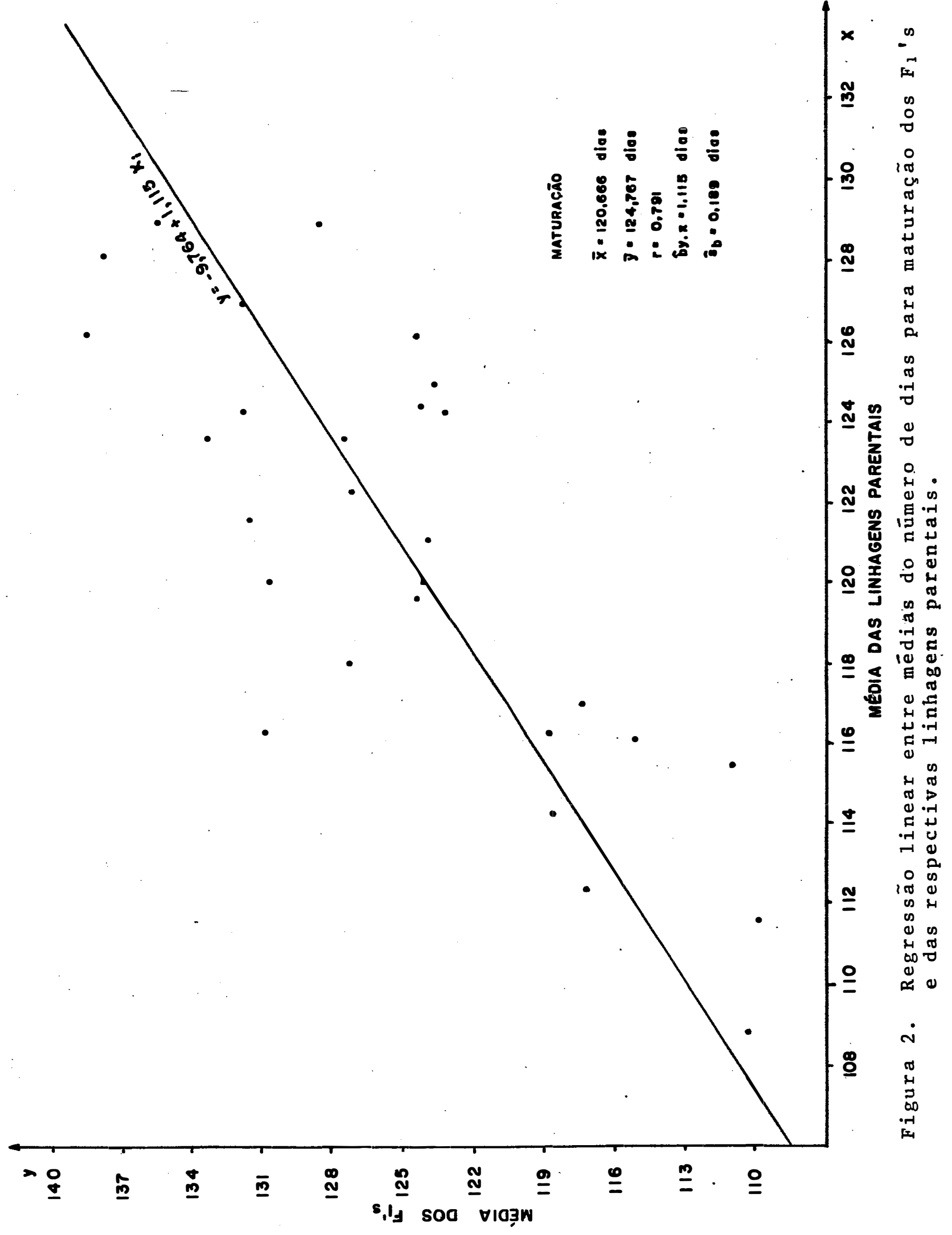




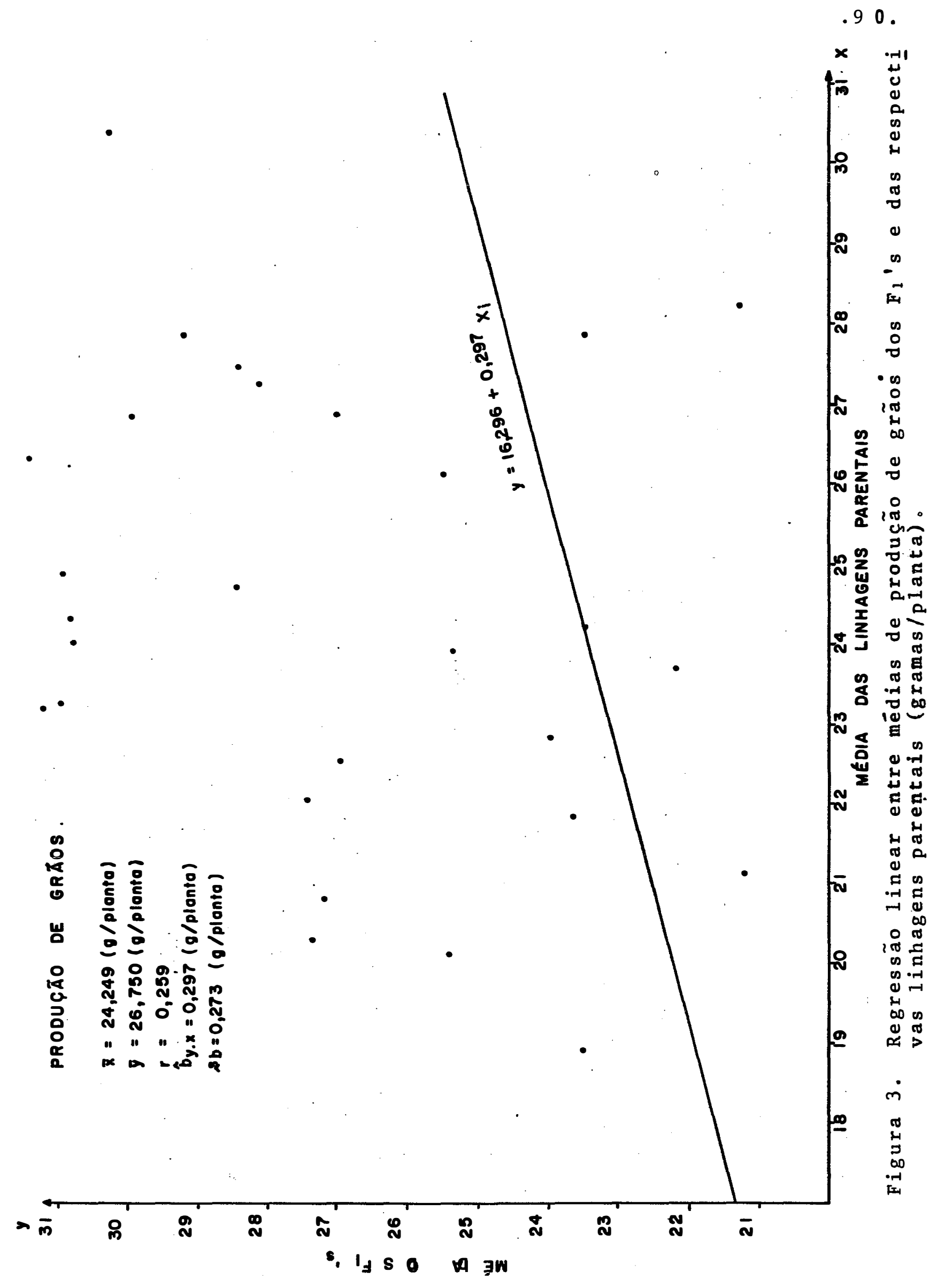


.91 .

APÊND ICE 
Tabela Al. Nümero de dias para início da floração ${ }^{\S}$ de oito linhagens e respectivos $F_{1}$ 's de soja. Blocos casualizados com seis repe tições, Londrina, 1980/81.

\begin{tabular}{|c|c|c|c|c|c|c|}
\hline Tratamento & $\mathrm{R}_{1}$ & $\mathrm{R}_{2}$ & $\mathrm{R}_{3}$ & $\mathbf{R}_{4}$ & $\mathrm{R}_{5}$ & $\mathrm{R}_{6}$ \\
\hline 1 & 36,0 & 37,0 & 35,5 & 38,0 & 37,5 & 36,5 \\
\hline 2 & 30,0 & 32,0 & 29,5 & 33,5 & 34,0 & 34,0 \\
\hline 3 & 28,0 & 26,0 & 25,0 & 26,0 & 26,5 & 26,0 \\
\hline 4 & 37,0 & $37,5\}$ & 36,5 & 37,5 & 37,5 & 36,5 \\
\hline 5 & 36,0 & 39,5 & 38,0 & 40,0 & 37,0 & 39,0 \\
\hline 6 & 27,5 & 29,5 & 26,0 & 27,5 & 30,0 & 29,0 \\
\hline 7 & 36,0 & 36,5 & 40,5 & 40,0 & 39,5 & 39,0 \\
\hline 8 & 42,5 & 41,0 & 42,0 & 41,5 & 43,0 & 44,5 \\
\hline $1 \times 2$ & 36,0 & 33,0 & 35,5 & 35,5 & 34,0 & 34,5 \\
\hline $1 \times 3$ & 30,0 & 29,5 & 30,0 & 32,0 & 31,5 & 31,0 \\
\hline $1 \times 4$ & 33,0 & 35,0 & 37,0 & 35,5 & 37,0 & 35,0 \\
\hline $1 \times 5$ & 37,5 & 35,0 & 35,5 & 36,0 & 35,0 & 36,5 \\
\hline $1 \times 6$ & 30,5 & 29,5 & 31,5 & 32,0 & 32,5 & 33,0 \\
\hline $1 \times 7$ & 36,5 & 33,0 & 37,5 & 38,0 & 39,5 & 38,5 \\
\hline $1 \times 8$ & 34,0 & 35,0 & 33,5 & 36,5 & 34,5 & 33,5 \\
\hline $2 \times 3$ & 29,0 & 32,5 & 27,0 & 31,5 & 32,5 & 30,5 \\
\hline $2 \times 4$ & 33,5 & 32,0 & 30,0 & 33,5 & 33,5 & 36,5 \\
\hline $2 \times 5$ & 32,0 & 31,5 & 35,0 & 34,0 & 34,0 & 34,5 \\
\hline $2 \times 6$ & 29,5 & 31,0 & 29,0 & 31,5 & 31,5 & 31,0 \\
\hline $2 \times 7$ & 30,0 & 32,5 & 32,0 & 36,0 & 34,0 & 34,0 \\
\hline $2 \times 8$ & 31,5 & 32,0 & 28,5 & 33,0 & 31,5 & 30,5 \\
\hline $3 \times 4$ & 29,5 & 31,0 & 32,5 & 29,0 & 33,0 & 30,0 \\
\hline $3 \times 5$ & 35,5 & 32,5 & 31,0 & 32,0 & 30,0 & 35,0 \\
\hline $3 \times 6$ & 26,0 & 26,5 & 26,0 & 28,5 & 31,0 & 27,5 \\
\hline $3 \times 7$ & 32,0 & 31,5 & 30,5 & 32,5 & 32,5 & 31,5 \\
\hline $3 \times 8$ & 29,0 & 30,5 & 32,0 & 30,5 & 30,0 & 32,0 \\
\hline $4 \times 5$ & 34,0 & 36,5 & 32,5 & 35,5 & 36,5 & 34,5 \\
\hline $4 \times 6$ & 32,0 & 29,0 & 32,0 & 31,5 & 32,0 & 29,5 \\
\hline $4 \times 7$ & 35,0 & 36,5 & 35,0 & 35,5 & 38,5 & 35,0 \\
\hline $4 \times 8$ & 32,0 & 33,0 & 33,0 & 32,5 & 34,5 & 30,0 \\
\hline $5 \times 6$ & 31,5 & 29,5 & 28,5 & $31,3 £$ & 28,0 & 35,5 \\
\hline $5 \times 7$ & 34,0 & 37,0 & 36,0 & 41,0 & 40,0 & 38,0 \\
\hline $5 \times 8$ & 36,0 & 35,0 & 34,5 & 34,0 & 35,0 & 35,5 \\
\hline $6 \times 7$ & 31,5 & 32,0 & 33,5 & 31,5 & 32,5 & 35,5 \\
\hline $6 \times 8$ & 33,0 & 31,0 & 29,0 & 31,0 & 32,5 & 32,5 \\
\hline $7 \times 8$ & 31,5 & 30,0 & 29,0 & 35,0 & 33,0 & 34,5 \\
\hline
\end{tabular}

$\S$ - Média de duas plantas;

£ - Valor estimado. 
Tabela A2. Número de dias para maturação§ de oito linhagens e respecti vos $\mathrm{F}_{1}$ 's dersoja. Blocos casualizados com seis repetições, Londrina, 1980/81.

\begin{tabular}{|c|c|c|c|c|c|c|}
\hline Tratamento & $\mathrm{R}_{1}$ & $\mathrm{R}_{2}$ & $\mathrm{R}_{3}$ & $\mathrm{R}_{4}$ & $\mathrm{R}_{5}$ & $\mathrm{R}_{6}$ \\
\hline 1 & 115,0 & 115,0 & 121,5 & 121,5 & 126,0 & 115,5 \\
\hline 2 & 102,0 & 110,0 & 99,5 & 102,5 & 108,0 & 103,0 \\
\hline 3 & 127,0 & 136,0 & 141,0 & 129,5 & 124,0 & 111,0 \\
\hline 4 & 115,5 & 122,5 & 123,0 & 109,5 & 127,0 & 124,0 \\
\hline 5 & 109,5 & 114,0 & 113,0 & 108,0 & 112,0 & 115,0 \\
\hline 6 & 124,5 & 121,0 & 134,0 & 130,5 & 132,0 & 136,0 \\
\hline 7 & 122,5 & 135,5 & 128,0 & 121,0 & 128,5 & 133,0 \\
\hline 8 & 112,0 & 129,0 & 125,0 & 125,0 & 127,5 & 126,0 \\
\hline $1 \times 2$ & 101,0 & 126,5 & 121,0 & 120,0 & 130,5 & 130,0 \\
\hline $1 \times 3$ & 126,5 & 130,5 & 130,0 & 119,0 & 129,0 & 128,5 \\
\hline $1 \times 4$ & 118,5 & 126,5 & 121,0 & 120,0 & 130,5 & 130,0 \\
\hline $1 \times 5$ & 107,5 & 107,5 & 111,5 & 111,5 & 111,0 & 119,0 \\
\hline $1 \times 6$ & 120,5 & 122,0 & 128,5 & 116,5 & 125,5 & 131,0 \\
\hline $1 \times 7$ & 130,5 & 129,5 & 131,0 & 128,0 & 140,0 & 135,5 \\
\hline $1 \times 8$ & 127,5 & 129,0 & 137,5 & 135,0 & 128,5 & 129,5 \\
\hline $2 \times 3$ & 110,5 & 111,0 & 121,0 & 116,0 & 131,0 & 124,0 \\
\hline $2 \times 4$ & 118,0 & 103,0 & 111,0 & 125,5 & 126,5 & 118,5 \\
\hline $2 \times 5$ & 109,0 & 101,5 & 108,0 & 118,5 & 115,0 & 108,5 \\
\hline $2 \times 6$ & 111,5 & 110,5 & 132,0 & 113,0 & 118,5 & 113,5 \\
\hline $2 \times 7$ & 130,0 & 132,5 . & 131,0 & 129,0 & 127,0 & 135,5 \\
\hline $2 \times 8$ & 121,0 & 121,0 & 127,0 & 110,5 & 121,0 & 111,0 \\
\hline $3 \times 4$ & 120,0 & 120,5 & 119,0 & 128,5 & 122,5 & 126,5 \\
\hline $3 \times 5$ & 138,0 & 135,0 & 140,0 & 138,5 & 137,0 & 136.0 \\
\hline $3 \times 6$ & 121,5 & 130,5 & 129,0 & 132,5 & 127,5 & 128,0 \\
\hline $3 \times 7$ & 138,0 & 135,0 & 140,0 & 138,5 & 137,0 & 136,0 \\
\hline $3 \times 8$ & 116,0 & 124,5 & 123,0 & 129,5 & 122,5 & 130,0 \\
\hline $4 \times 5$ & 120,0 & 109,5 & 108,5 & 117,0 & 123,5 & 112,0 \\
\hline $4 \times 6$ & 133,0 & 116,0 & 122,0 & 129,0 & 121,5 & 120,5 \\
\hline $4 \times 7$ & 121,0 & 129,5 & 132,0 & 137,0 & 133,5 & 135,5 \\
\hline $4 \times 8$ & 122,0 & 119,5 & 136,0 & 115,5 & 133,0 & 136,0 \\
\hline $5 \times 6$ & 110,0 & 129,5 & 126,0 & $123,8^{£}$ & 134,0 & 120,0 \\
\hline $5 \times 7$ & 126,0 & 133,5 & 126,0 & 122,0 & 135,0 & 140,5 \\
\hline $5 \times 8$ & 117,0 & 130,5 & 126,0 & 130,0 & 129,5 & 130,0 \\
\hline $6 \times 7$ & 135,5 & 136,5 & 130,0 & 134,0 & 137,0 & 138,5 \\
\hline $6 \times 8$ & 123,0 & 127,5 & 129,0 & 137,0 & 141,0 & 121,0 \\
\hline $7 \times 8$ & 134,0 & 139,5 & 140,0 & 139,5 & 135,0 & 142,0 \\
\hline
\end{tabular}

$\S$ - Média de duas plantas;

£ - Valor estimado. 
Tabela A3. Produção de grãos $§$ (g/planta) de oito linhagens e respectị vos $F_{1}{ }^{i}$ 's de soja. Blocos casualizados com seis repetições, Londrina, $1980 / 81$.

\begin{tabular}{|c|c|c|c|c|c|c|}
\hline Tratamento & $\mathrm{R}_{1}$ & $\mathrm{R}_{2}$ & $\mathrm{R}_{3}$ & $\mathrm{R}_{4}$ & $\mathrm{R}_{5}$ & $\mathrm{R}_{6}$ \\
\hline 1 & 17,35 & 20,15 & 26.15 & 18,55 & 18.60 & 22.85 \\
\hline 2 & 24,00 & 18,65 & 28,35 & 21,50 & 18,25 & $\begin{array}{l}22,85 \\
29,45\end{array}$ \\
\hline 3 & 20,85 & $16,575^{f}$ & 14,95 & 12,85 & 21,20 & 16,30 \\
\hline 4 & 22,90 & 27,20 & 21,90 & 21,60 & 27,00 & 25,45 \\
\hline 5 & 23,90 & 33,00 & 31,50 & 28,45 & 26,65 & 31,50 \\
\hline 6 & 25,30 & 24,05 & 20,70 & 20,00 & 16,90 & 19,05 \\
\hline 7 & 30,90 & 17,50 & 28,60 & 22,25 & 24,05 & 26,60 \\
\hline 8 & 34,65 & 34,75 & 32,50 & 28,55 & 32,00 & 25,90 \\
\hline $1 \times 2$ & 30,55 & 24,20 & 30,60 & 27,30 & 28,00 & 22,60 \\
\hline $1 \times 3$ & 20,90 & 22,00 & 22,95 & 24,40 & 19,50 & 29,80 \\
\hline $1 \times 4$ & 28,95 & 24,30 & 29,20 & 26,20 & 23,50 & 27,90 \\
\hline $1 \times 5$ & 36,15 & 27,40 & 33,05 & 28,50 & 29,00 & 30,75 \\
\hline $1 \times 6$ & 22,70 & 21,85 & 23,85 & 24,95 & 19,15 & 27,85 \\
\hline $1 \times 7$ & 24,70 & 21,45 & 22,35 & 24,55 & 21,50 & 27,30 \\
\hline $1 \times 8$ & 26,40 & 22,60 & 24,10 & 21,15 & 29,25 & 28,00 \\
\hline $2 \times 3$ & 28,70 & 25,45 & 33,30 & 24,00 & 24,30 & 27,05 \\
\hline $2 \times 4$ & 23,60 & $27:, 25$ & 33,25 & 20,65 & 20,30 & 25,65 \\
\hline $2 \times 5$ & 31,15 & 31,25 & 28,75 & 28,35 & 38,00 & 30,85 \\
\hline $2 \times 6$ & 32,85 & 29,30 & 29,30 & 29,35 & 34,25 & 29,20 \\
\hline $2 \times 7$ & 19,70 & 20,35 & 20,65 & 27,85 & 28,15 & 24,10 \\
\hline $2 \times 8$ & 25,45 & 28,85 & 29,20 & 29,45 & 24,15 & 32,35 \\
\hline $3 \times 4$ & 27,40 & 24,70 & 22,55 & $26,425^{£}$ & 29,05 & 31,75 \\
\hline $3 \times 5$ & 29,50 & 32,50 & 30,85 & 29,45 & 36,30 & 26,40 \\
\hline $3 \times 6$ & 27,85 & 21,15 & 22,90 & 27,20 & 25,90 & 26,15 \\
\hline $3 \times 7$ & 21,70 & 23,85 & 20,55 & 16,05 & 24,90 & 18,85 \\
\hline $3 \times 8$ & 32,80 & 29,05 & 29,30 & 25,90 & 31,75 & 34,30 \\
\hline $4 \times 5$ & 23,30 & 26,60 & 32,75 & 32,45 & 27,20 & 35,75 \\
\hline $4 \times 6$ & 20,10 & 19,80 & 23,40 & 19,50 & 26,80 & 21,45 \\
\hline $4 \times 7$ & 29,45 & 24,85 & 25,95 & 23,55 & 34,00 & 31,20 \\
\hline $4 \times 8$ & 17,25 & 33,00 & 19,60 & 26,85 & 23,25 & 19,75 \\
\hline $5 \times 6$ & 33,25 & 26,65 & 30,20 & 28,75 & 17,80 & 24,35 \\
\hline $5 \times 7$ & 22,90 & 31,05 & 32,30 & 28,00 & 27,20 & 22,20 \\
\hline $5 \times 8$ & 26,60 & 26,90 & 30,20 & 39,50 & 28,15 & 29,15 \\
\hline $6 \times 7$ & 29,60 & 27,80 & 39,25 & 27,50 & 27,10 & 32,55 \\
\hline $6 \times 8$ & 32,45 & 30,05 & 27,05 & 26,35 & 24,30 & 35,60 \\
\hline $7 \times 8$ & 20,75 & 14,85 & 20,35 & 16,90 & 27,85 & 25,50 \\
\hline
\end{tabular}

$\S$ - Média de duas plantas;

E - Valor estimadó. 